(C) 2021, The Authors. Published by Elsevier Inc. and Fass Inc. on behalf of the American Dairy Science Association ${ }^{\circledR}$. This is an open access article under the CC BY-NC-ND license (http://creativecommons.org/licenses/by-nc-nd/4.0/).

\title{
Differing planes of pre- and postweaning phase nutrition in Holstein heifers: I. Effects on feed intake, growth efficiency, and metabolic and development indicators
}

\author{
J. P. Rosadiuk, ${ }^{1}$ T. C. Bruinjé, ${ }^{1,2}$ F. Moslemipur, ${ }^{3}$ A. J. Fischer-Tlustos, ${ }^{4}$ D. L. Renaud, ${ }^{2}$ D.J. Ambrose,,${ }^{1,5}$ \\ and M. A. Steele (1,4* $^{\text {. }}$ \\ ${ }^{1}$ Department of Agricultural, Food and Nutritional Science, University of Alberta, Edmonton, AB, Canada, T6G 2P5 \\ ${ }^{2}$ Department of Population Medicine, University of Guelph, Guelph, ON, Canada, N1H 2W1 \\ ${ }^{3}$ Department of Animal Science, Gonbad Kavoos University, PO Box 163, Golestan, Iran, 49717-99151 \\ ${ }^{4}$ Department of Animal Biosciences, University of Guelph, Guelph, ON, Canada, N1G 2W1 \\ ${ }^{5}$ Livestock Research Branch, Alberta Agriculture and Forestry, Edmonton, AB, Canada, T6H 5T6
}

\section{ABSTRACT}

The objectives of this study were to determine the effects of pre- and postweaning planes of nutrition on feed and metabolizable energy (ME) intake, growth, concentrations of glucose, insulin, insulin-like growth factor 1 (IGF-1), and $\beta$-hydroxybutyrate (BHB) in blood and rumen volatile fatty acids (VFA) from birth to $25 \mathrm{wk}$ of age in Holstein heifers. Heifer calves $(\mathrm{n}=36)$ were randomly assigned to receive either a low $(5 \mathrm{~L} / \mathrm{d}$ of whole milk) or high (10 L/d of whole milk) preweaning plane of nutrition from 1 to $7 \mathrm{wk}$ of age, and either a low (70\% concentrate dry total mixed ration) or high (85\% concentrate dry total mixed ration) postweaning plane of nutrition from 11 to 25 wk of age. From birth to 25 wk of age, feed intake was recorded daily, and body measures were obtained weekly. Circulating hormone and metabolite concentrations were measured biweekly and total ruminal VFA, fecal starch, and body condition were assessed monthly. Overall, average daily gain and body weight were greater for heifers offered increased planes of nutrition during both the pre- and postweaning phases. Heifers offered the high preweaning plane had greater milk intake $(7.7 \pm 0.1$ vs. $4.5 \pm$ $0.1 \mathrm{~L} / \mathrm{d})$ but lower starter intake $(0.3 \pm 0.04$ vs. 0.7 $\pm 0.04 \mathrm{~kg} / \mathrm{d}$ ) during the preweaning phase than those offered the low plane. High preweaning plane heifers also had greater ME intake from wk 1 to 7, but less ME intake at wk $9(5.3 \pm 0.3$ vs. $6.6 \pm 0.2 \mathrm{Mcal} / \mathrm{kg})$ than those offered the low plane. Furthermore, overall glucose $(118.8 \pm 2.9$ vs. $110.1 \pm 2.9 \mathrm{mg} / \mathrm{dL})$ and IGF-1 $(101.6 \pm 3.6$ vs. $75.9 \pm 3.6 \mathrm{ng} / \mathrm{mL})$ concentrations were greater for high versus low preweaning plane heifers, although circulating insulin and BHB did not differ

Received April 29, 2020

Accepted July 28, 2020.

*Corresponding author: masteele@uoguelph.ca between preweaning plane groups. However, heifers offered the high preweaning plane had reduced total rumen VFA concentrations compared with heifers offered the low plane in the preweaning phase $(47.3 \pm$ 2.0 vs. $55.6 \pm 2.1 \mathrm{mM}$ ). During the postweaning phase, dry matter intake and ME were consistently greater in heifers offered the high postweaning plane. Overall insulin $(2.0 \pm 0.1$ vs. $1.8 \pm 0.1 \mathrm{ng} / \mathrm{mL})$, glucose $(97.1 \pm$ 0.6 vs. $92.1 \pm 0.6 \mathrm{ng} / \mathrm{mL}), \mathrm{IGF}-1(178.0 \pm 4.8$ vs. 155.8 $\pm 4.8 \mathrm{ng} / \mathrm{mL})$, and BHB concentrations $(8.8 \pm 0.2$ vs. $8.1 \pm 0.2 \mathrm{ng} / \mathrm{mL}$ ) were greater in heifers offered the high than the low postweaning plane. In addition, heifers offered the high postweaning plane had increased VFA concentrations in the postweaning phase (73.4 \pm 1.3 vs. $63.9 \pm 1.3 \mathrm{mM}$ ) compared with heifers offered the low postweaning plane. The results indicated that increasing the pre- and postweaning planes of nutrition along with energy levels positively influenced several indicators associated with heifer development before 25 wk of age. Nevertheless, there was limited interaction in growth and development indicators between the 2 phases.

Key words: dairy calf, dairy heifer, plane of nutrition, growth and development

\section{INTRODUCTION}

In recent years, research focused on the growth and development of replacement heifer calves on dairy operations has increased due to greater priority being placed on successful early-life development, which can have short and long-term implications on health, welfare, and production. While technologies, management, and genetics all play a role in improving heifer development, enhancing nutritional provision may be a highly cost-effective strategy to maximize heifer growth and development. The majority of the costs associated with rearing heifers from birth to first calving are incurred 
due to feed (Heinrichs et al., 2013), yet providing more high-quality feed and improving early-life growth rates can increase future production and reduce heifer development costs through decreased veterinary expenses, labor, and housing (Overton et al., 2013). For instance, providing an elevated plane of nutrition to calves has led to improved immune response (Ollivett et al., 2012), welfare (Thomas et al., 2001; Krachun et al., 2010), and growth rates similar to those that occur in suckling calves (Drackley, 2008). Therefore, altering early-life nutritional provision from conventional feeding schemes can potentially improve the efficiency of heifer rearing and the profitability of operations.

The majority of nutritional studies conducted with heifer calves have focused on the preweaning phase of life. Improving nutritional provision in the preweaning phase, generally through increased volumes of milk or greater milk protein content, has led to increased intake (Khan et al., 2011), growth (Diaz et al., 2001), blood concentrations of IGF-1 and leptin (Brown et al., 2005), mammary development (Geiger et al., 2016), number of ovarian follicles (Bruinjé et al., 2019), and lifetime production (Bach, 2011; Soberon et al., 2012). Some studies have also emphasized increased growth in the postweaning or prepubertal phase, generally through the provision of high energy and protein content concentrates $[2.8 \mathrm{Mcal} / \mathrm{kg}$ of $\mathrm{ME}$ and $19.7 \% \mathrm{CP}$ by Radcliff et al. (2000); $3.6 \mathrm{Mcal} / \mathrm{kg}$ of ME and 20.0\% CP by Brown et al. (2005)]. Such studies report improved growth and gain:feed ratio (Brown et al., 2005), reduced ages at first breeding and at first calving (Radcliff et al., 2000), enhanced development of the reproductive tract (Bruinjé et al., 2019), and reduced feed costs through a reduction in nonproductive days on feed (Overton et al., 2013). The primary concern with increased early-life growth, especially in the prepubertal stage of life, is that the growth of the mammary gland will be impaired through increased fat deposition or a shortening of the allometric growth phase (Sejrsen and Purup, 1997). There is a lack of understanding regarding how diet can affect mammary gland development, as the studies have conflicting mammary development results due to a wide range of nutritional treatments (Whitlock et al., 2002; Davis Rincker et al., 2008b; Capuco and Akers, 2010; Geiger et al., 2015). The paucity of studies examining the effects of both pre- and postweaning planes of nutrition further complicates attempts to rear heifer calves to their full potential.

Understanding the potential effects of early-life nutrition in Holstein heifers is necessary to improve and optimize the rearing process, especially in the pre- and postweaning phases. The objectives of the present study were to determine the effects of pre- and postweaning planes of nutrition with differing energy levels on (1) daily feed and ME intake, (2) growth, and (3) concentrations of key metabolites and hormones, including glucose, insulin, IGF-1, BHB, and rumen VFA, from birth to 25 wk of age in Holstein heifer calves. We hypothesized that (1) increasing pre- and postweaning planes of nutrition would enhance development through increased ME intake, growth, and increased hormone and metabolite concentrations and (2) differing planes of nutrition in the preweaning period would influence the association between postweaning plane of nutrition and overall heifer development.

\section{MATERIALS AND METHODS}

The experimental procedures used in this study were approved by the Animal Care and Use Committee for Livestock, University of Alberta (AUP no. 00001553), and animals were cared for in accordance with the guidelines of the Canadian Council of Animal Care (Ottawa, ON, Canada). The current study was performed in conjunction with Bruinjé et al. (2019), in which experimental protocols were previously described.

\section{Animals, Housing, and Feeding Schemes}

Thirty-six singlet Holstein heifer calves born between February and August 2017 at the University of Alberta's Dairy Research and Technology Centre (Edmonton, AB, Canada) were enrolled in this study (mean birth $\mathrm{BW} \pm \mathrm{SD}=39.1 \pm 3.5 \mathrm{~kg}$ ). An estimated sample size of at least 14 heifers per preweaning dietary treatment group was required to detect differences in ADG and BW by the end of the preweaning period (Davis Rincker et al., 2011) with $80 \%$ power and $\alpha=$ 0.05. For postweaning dietary treatment, a sample size of at least 8 heifers per group was required to detect differences in BW and IGF-1 (Chelikani et al., 2009). Treatment assignments were randomized for every 4 calves born by randomly drawing from a hat 1 of the 4 treatment subgroups described in the latter part of this section. For the preweaning phase, assignments were based on previous experiments in the same facility (Haisan et al., 2018) to either a low $(\mathrm{n}=18 ; 5 \mathrm{~L} / \mathrm{d})$ or high $(\mathrm{n}=18 ; 10 \mathrm{~L} / \mathrm{d})$ preweaning diet of pasteurized (DairyTech, Greeley, CO) whole milk $\left(60^{\circ} \mathrm{C}\right.$ for $60 \mathrm{~min}$ collected from saleable milk pool) from wk 1 to 7 . For the postweaning phase, calves were assigned to either a low ( $\mathrm{n}=18 ; 30 \%$ straw and $70 \%$ concentrate) or high $(\mathrm{n}=18 ; 15 \%$ straw and $85 \%$ concentrate) ad libitum postweaning diet (as further described) from 11 until the end of wk 25 of age. Given the pre- and postweaning dietary treatments, 4 treatment subgroups ( $\mathrm{n}=$ 9 per subgroup) were evaluated: low preweaning, low postweaning diets; low preweaning, high postweaning 
Table 1. Ingredient and chemical composition of the dietary planes of nutrition (low vs. high) provided in the pre- and postweaning phases to 36 Holstein heifer calves

\begin{tabular}{|c|c|c|}
\hline Item & Low & High \\
\hline \multicolumn{3}{|l|}{ Preweaning phase $^{1}$} \\
\hline \multicolumn{3}{|l|}{ Pasteurized whole milk } \\
\hline Amount fed (L/d) & 5.0 & 10.0 \\
\hline \multicolumn{3}{|l|}{ Chemical composition } \\
\hline $\mathrm{CP}(\%$ of $\mathrm{DM})$ & 24.8 & 24.8 \\
\hline Crude fat ( $\%$ of DM) & 30.3 & 30.3 \\
\hline ME (Mcal/kg of DM) & 4.6 & 4.6 \\
\hline \multicolumn{3}{|l|}{ Starter/Concentrate } \\
\hline \multicolumn{3}{|l|}{ Chemical composition } \\
\hline $\mathrm{CP}(\%$ of $\mathrm{DM})$ & 22.4 & 22.4 \\
\hline Crude fiber ( $\%$ of DM) & 7.6 & 7.6 \\
\hline Starch (\% of DM) & 22.3 & 22.3 \\
\hline ME (Mcal/kg of DM) & 2.6 & 2.6 \\
\hline \multicolumn{3}{|l|}{ Straw } \\
\hline \multicolumn{3}{|l|}{ Chemical composition } \\
\hline $\mathrm{CP}(\%$ of $\mathrm{DM})$ & 4.6 & 4.6 \\
\hline NDF ( $\%$ of DM) & 71.6 & 71.6 \\
\hline ME (Mcal/kg of DM) & 1.6 & 1.6 \\
\hline \multicolumn{3}{|l|}{ Postweaning phase $^{2}$} \\
\hline \multicolumn{3}{|l|}{ Ingredient ( $\%$ of DM) } \\
\hline Rumimax pellets ${ }^{3}$ & 46.5 & 56.5 \\
\hline Beet pulp pellets & 10.8 & 13.0 \\
\hline Rolled corn & 10.5 & 12.8 \\
\hline Molasses & 2.10 & 2.6 \\
\hline Flavoring agent & 0.1 & 0.1 \\
\hline Concentrate & 70.0 & 85.0 \\
\hline Wheat straw & 30.0 & 15.0 \\
\hline \multicolumn{3}{|l|}{ Chemical composition } \\
\hline $\mathrm{CP}(\%$ of $\mathrm{DM})$ & 21.1 & 25.0 \\
\hline $\mathrm{NDF}(\%$ of $\mathrm{DM})$ & 46.0 & 30.1 \\
\hline ME (Mcal/kg of DM) & 2.5 & 2.9 \\
\hline
\end{tabular}

${ }^{1}$ Preweaning dietary planes of nutrition occurred between 1 and $7 \mathrm{wk}$ of age, followed by a weaning transition ( $10 \%$ daily reduction in milk offered) from 7 to 9 wk of age. From 9 to 11 wk of age, heifer calves received a transition diet with $85 \%$ starter and $15 \%$ straw.

${ }^{2}$ Postweaning dietary plane of nutrition occurred between 11 and 26 wk of age and contained either a $70 \%$ (low postweaning plane) or $85 \%$ (high postweaning plane) concentrate dry TMR.

${ }^{3}$ Trouw Nutrition, Guelph, ON, Canada.

diets; high preweaning, low postweaning diets; and high preweaning, high postweaning diets. Free choice water was available to all heifers for the entire study period, in which heifer calves were enrolled from birth until 25 wk of age. Ingredient and chemical composition of the pre- and postweaning dietary planes of nutrition are presented in Table 1.

A feeding and housing summary for the heifers is presented in Figure 1. Immediately after birth, calves were allowed to be licked by the dam before being placed in individual stalls bedded with wood shavings and wheat straw. Within $2 \mathrm{~h}$ of birth, all calves were offered $2 \mathrm{~L}$ of reconstituted powdered colostrum (minimum guaranteed analysis bovine IgG of $60 \mathrm{~g} / \mathrm{L}$; Headstart Bovine Dried Colostrum, The Saskatoon Colostrum Company Ltd., Saskatoon, SK, Canada) via nipple bottle. All refusals from the bottle feeding were delivered to the calves via esophageal tube. After the first feeding, all calves were offered 3 additional 2-L feedings of pooled and pasteurized (at $60^{\circ} \mathrm{C}$ for $60 \mathrm{~min}$ ) maternal colostrum at 8,16 , and $24 \mathrm{~h}$ after the first feeding. Only colostrum measuring greater than $23 \%$ with a BRIX refractometer (Misco Refractometer, Solon, OH) was used to ensure a minimum IgG concentration in the pooled colostrum of $50 \mathrm{~g} / \mathrm{L}$ or greater (Bielmann et al., 2010). After the 4 colostrum feedings, calves were trained to use a calf rail system (Foerster-Technik, Engen, Germany) where 2.5-L meals of whole milk were delivered 4 times daily to calves receiving the high preweaning diet, and twice daily to calves receiving the low preweaning diet. The portable calf rail system offered milk to calves based on sensors assigned to individual pens, and the system was calibrated weekly to ensure accurate measures. Feeding times were 0615, 1130,1630 , and $2200 \mathrm{~h}$ for high preweaning diet calves, and 0615 and 1630 for low preweaning diet calves. The milk fed to calves was sampled daily throughout the experiment and averaged $24.8 \pm 0.3 \% \mathrm{CP}(\mathrm{DM})$ and $30.3 \pm 0.7 \%$ crude fat $(\mathrm{DM})$, while ME content was 4.6 Mcal $/ \mathrm{kg}$. From d $7 \pm 1$ to $\mathrm{d} 21 \pm 1$, calves had access to free choice texturized starter $(22.4 \% \mathrm{CP}, 7.6 \%$ crude fiber, $2.9 \%$ crude fat, $22.3 \%$ starch, texturized; Trouw Nutrition, Guelph, ON, Canada) from a bucket, which was emptied and weighed back twice weekly to monitor intake. Ad libitum access to water from a bucket was available to all calves in this period. At d $21 \pm 1$, calves were moved to a group pen bedded with wheat straw and offered milk through a stationary automated feeder (CF1000+, DeLaval Canada, Peterborough, ON, Canada). The same starter continued to be offered free choice using BioControl bunks (BioControl, Rakkestad, Norway), which identified calves through radio frequency identification tags and monitored feed disappearance on a calf-by-calf as-fed basis. BioControl bunks were calibrated on a biweekly basis and debris removed from scale load cells daily to ensure accurate measurements. Free choice chopped straw (Skyline Harvest, Blumenort, MB, Canada; 2.54-cm chop length, $4.6 \% \mathrm{CP}, 71.6 \% \mathrm{NDF}, 1.6 \mathrm{Mcal} / \mathrm{kg}$ of $\mathrm{ME}$ ) was made available to all calves via BioControl bunks (in addition to the starter bunks) on d $21 \pm 1$; however, intake was not monitored throughout the preweaning period given the minimal amounts ingested, and calves were bedded with straw bedding. All feed intake data were collected on an as-fed basis, and DMI was calculated based on monthly DM analysis of feed.

A 10-d weaning transition began at $50 \mathrm{~d}$ of age, when the total volume of milk was gradually reduced by $10 \% / \mathrm{d}$ for all treatment groups. All calves were completely weaned from milk on d 60. Calves continued to 


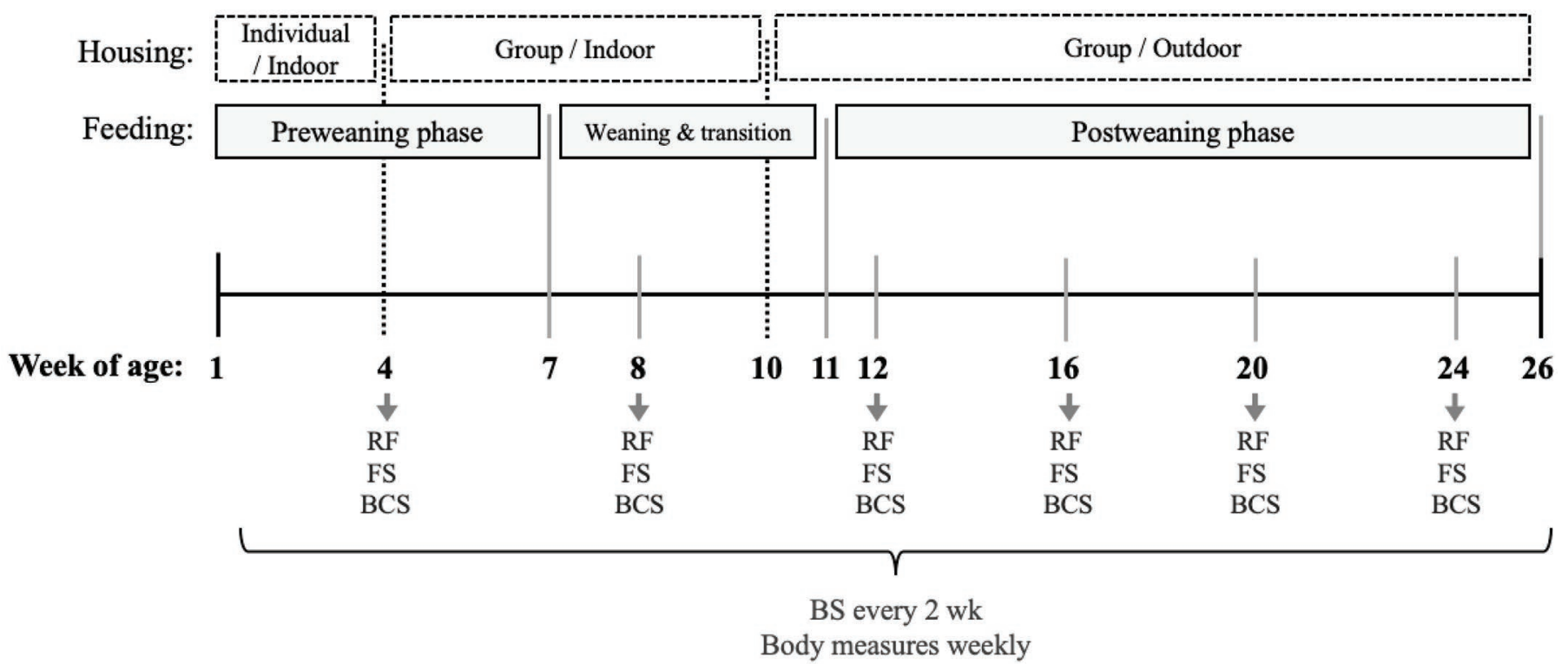

Figure 1. A schematic diagram of animal feeding throughout the 25-wk study. At d 1 and 2 of life, calves were fed colostrum. After, calf rail feeding of each respective preweaning plane of nutrition treatment began. Starting at wk 2, calves were given ad libitum starter access and at wk 4 calves were moved to indoor group housing with a stationary feeder. Weaning stepdown began at wk 7 , and at wk 9 calves were fully weaned. From wk 9 to 11, all calves were fed a high plane TMR as a transition onto the postweaning dietary plane of nutrition. At the end of wk 10, all calves were moved to an outdoor facility with group housing. From wk 11 until the end of wk 25, heifers offered the low postweaning plane were fed a low plane TMR, while heifers offered the high postweaning plane continued on the same postweaning diet as fed from wk 9. Ruminal fluid (RF) to assess VFA, fecal sample (FS) to assess fecal starch and DM, and BCS were obtained monthly. Blood samples (BS) to assess IGF-1, insulin, glucose, and BHB concentrations were collected every $2 \mathrm{wk}$, and body measures (BW, heart girth, withers height) were obtained weekly.

have access to separate straw and starter for $5 \mathrm{~d}$; however, on d 65 these components were combined to form a dry TMR ( $85 \%$ starter, $15 \%$ chopped straw by weight; Table 1), which all heifers had access to until d 80. Heifers were transported to an outdoor group-housed facility at $10 \mathrm{wk}(\sim 75 \mathrm{~d})$ of age. Three paddocks bedded with wheat straw and equal shelter were available to the heifers within each paddock. Heifers were fitted with magnetic collars and assigned an individual automated feed bunk (Calan Broadbent Feeding System, American Calan Inc., Northwood, NH). Upon arrival, heifers were individually penned for $3 \mathrm{~d}$ to completely train them to use the feeding system. At 11 wk $(\sim 80 \mathrm{~d})$ of age, the low preweaning diet heifers were abruptly changed to the low postweaning diet containing $70 \%$ starter and 30\% chopped straw by weight (Table 1). The high postweaning diet heifers continued to receive the same ration (85\% starter and 15\% chopped straw) until the end of $25 \mathrm{wk}(\sim 180 \mathrm{~d})$ of age. For all heifers, feed allocation was adjusted daily to allow for ad libitum intake and refusals of less than $10 \%$. Feed intake was recorded at $0800 \mathrm{~h}$ on a daily basis throughout the study. Once heifers were transitioned to the TMR, the amount of feed refused was weighed before feeding each day. Feed allocation was increased by $0.2 \mathrm{~kg}$ when refusals were less than $10 \%$ for 3 consecutive days. For each dietary treatment group, feed was mixed once weekly. Health treatments were administered according to protocols developed with the herd veterinarian and recorded. No abnormal health conditions were observed in calves enrolled in this study.

\section{Samples and Data Collection}

Throughout the study period from wk 1 to 25 of age, blood samples were collected every 2 wk at $3 \mathrm{~h}$ after morning feeding. Heifers were manually restrained, and a total of $20 \mathrm{~mL}$ of blood was collected from the jugular vein and placed into tubes containing silica or lithium heparin $(10 \mathrm{~mL}$; BD Vacutainer, Franklin Lakes, NJ) for harvest of serum and plasma, respectively. Serum tubes were incubated at room temperature for $1 \mathrm{~h}$ before centrifugation. Immediately following collection, $0.5 \mu \mathrm{L}$ of aprotinin from bovine lung (Sigma-Aldrich Canada Co., Oakville, ON, Canada) per mL of blood collected was pipetted into the plasma tubes, inverted 5 times, and placed on ice before centrifugation. Centrifugation occurred for $20 \mathrm{~min}$ at $4^{\circ} \mathrm{C}$ and $3,000 \times g$ before the supernatant was aliquoted and stored at $-20^{\circ} \mathrm{C}$ until assayed for concentrations of glucose, insulin, IGF-1, and BHB. Body weight was measured on a weekly basis using a digital weigh scale (Salter Brecknell PS-2000, Fairmount, MN) that was calibrated before each use. Body measures were recorded weekly, with hip height 
and wither height measured using a telescoping measuring stick (Nasco, Atkinson, MN), and heart girth and barrel girth recorded by using a measuring tape (Nasco). Average daily gain was calculated on a 4 -wk basis to reduce variability due to heifers being weighed once weekly.

Body condition score, rumen fluid, and fecal samples were collected at the end of wk 4, 8, 12, 16, 20, and 24 (Figure 1). Body condition score was determined by a single trained observer, blinded to the treatment assigned. Rumen fluid was collected using an adapted version of the process and equipment described by Geishauser (1993). In brief, a custom-made bronze probe (Grayco Machine, Leduc, AB, Canada) was attached to a 4-ft reinforced vinyl pipe (Watts Canada, Burlington, ON, Canada) and introduced into the rumen via the esophagus. Once the probe was introduced into the rumen, a $100-\mathrm{mL}$ syringe was used to collect fluid. Approximately $20 \mathrm{~mL}$ of rumen fluid was collected and filtered through cheese cloth (Uline Canada, Milton, ON, Canada), transferred to 2 sterile $10-\mathrm{mL}$ tubes, and snap frozen in liquid nitrogen before being stored at $-20^{\circ} \mathrm{C}$ until analysis.

\section{Sample Analysis}

Concentrations of plasma glucose were determined by using a quantitative enzymatic assay (Sigma-Aldrich Canada Co.) and dianisidine dihydrochloride as substrate (Sigma-Aldrich Canada Co.). Standard curves from 0 to $100 \mathrm{mg}$ of glucose $/ \mathrm{mL}$ were then prepared using distilled water and stock solution and ran in duplicate. The absorbance of the samples was read at $450 \mathrm{~nm}$ by a SpectraMax 190 plate reader (Molecular Devices Corp., Sunnyvale, CA) in duplicate. Inter- and intra-assay coefficients of variation (CV) were $1.5 \%$ and $1.0 \%$, respectively.

Plasma concentrations of insulin were analyzed using a competitive solid-phase immunoassay previously described by Takahashi et al. (2006). Plates were coated with anti-guinea pig gamma globulin antiserum (second antibody) before diluted antibody to human insulin (first antibody) was added and incubated overnight. Following incubation, plates were washed, and standards and plasma samples were added to the wells and again incubated overnight. On the third day, europiumlabeled insulin was added to each well and incubated at $6^{\circ} \mathrm{C}$ for $2 \mathrm{~h}$ before the plate was washed, enhancement solution added to each well, and fluorescence measured. Inter- and intra-assay CV were $12.4 \%$ and $7.1 \%$, respectively.

Serum IGF-1 concentrations were quantified using an Immulite IGF-1 kit, which is an established solid-phase, enzyme-labeled chemiluminescent immunometric assay
(Siemens Healthcare Limited, Oakville, ON, Canada) at the Endocrine Service Lab of the University of Saskatchewan (Saskatoon, SK, Canada). The overall interand intra-assay CV were $5.1 \%$ and $4.5 \%$, respectively.

Plasma BHB concentrations were determined using the enzymatic oxidation of BHB to acetoacetate with 3-hydroxybutrate dehydrogenase. Briefly, $4.9 \mathrm{~g}$ of Tris (hydroxymethyl) aminomethane was diluted to a $\mathrm{pH}$ of 9.0 using distilled water. Plasma samples and standards were added to the plates and shaken for $15 \mathrm{~s}$ before being placed in the reader at $340 \mathrm{~nm}$. Initial readings were recorded before $10 \mu \mathrm{l}$ of 3-hydroxybutyrate dehydrogenase (Hoffman-La Roche Ltd., High River, AB, Canada) was added to each well and agitated again for $15 \mathrm{~s}$. Plates were covered with a plate lid before being incubated at $38.5^{\circ} \mathrm{C}$ for $1 \mathrm{~h}$, and again read at $340 \mathrm{~nm}$, with the increase in absorbance directly proportional to the amount of BHB in the sample. The inter- and intra-assay CV were $4.5 \%$ and $2.8 \%$, respectively.

Total VFA concentration of ruminal fluid was determined by gas chromatography as described by Schlau et al. (2012). In brief, 25\% (vol/vol) phosphoric acid was added to thawed rumen fluid samples at a volume rate of 1:4 (phosphoric acid:rumen fluid sample) before centrifugation. Gas chromatography vials were loaded with $1 \mathrm{~mL}$ of sample solution and $200 \mu \mathrm{l}$ of internal standard solution and assayed in duplicate on a Varian gas chromatograph (Model 3400; Varian Inc., Walnut Creek, CA). Inter- and intra-assay CV for VFA concentrations were $0.7 \%$ and $0.9 \%$, respectively. Fecal samples were collected $3 \mathrm{~h}$ after the morning feeding and stored at $-20^{\circ} \mathrm{C}$ before analysis (AOAC International, 2000) for fecal DM (oven method 930.15) and fecal starch ( $\alpha$-amylase method; Hall, 2009). Effects of the dietary treatments on circulating leptin concentrations, luteinizing hormone, and age at puberty are reported in a companion paper (Bruinjé et al., 2020 in review).

\section{Statistical Analysis}

Statistical analyses were performed using SAS (Studio 3.8 platform, SAS Institute, Cary, NC). Descriptive statistics were obtained using the MEANS procedure and variables analyzed as Gaussian distributions using the GLIMMIX procedure. For each dependent variable, the model for the preweaning phase included the fixed effects of preweaning diet, time point (week or month), and their interactions, with birth BW included as a covariate and heifer as the repeated measures subject. Models for the postweaning phase included the fixed effects of preweaning diet, postweaning diet, time point, and their interactions, with birth $\mathrm{BW}$ as a covariate and heifer as the repeated measures subject. For each model, the covariance structure with the lowest Bayes- 
ian information criterion was chosen. Interactions were initially included in the models and removed using a manual backward stepwise approach if their effects had $P>0.10$, deliberately keeping both pre- and postweaning dietary treatments in the final models. Posthoc tests were performed using Bonferroni adjustment and least squares means (LSM) by each time point assessed using the SLICE command. Normality and homoscedasticity of the residuals were assessed graphically through standardized residuals. If the assumption of normality was not met, data were investigated for removal of potential outliers or logarithmic transformations were used. Results were reported as LSM \pm standard error for normal data and as the back-transformed LSM with their respective $95 \%$ confidence interval for $\log$-transformed data. Significance was declared at $P \leq$ 0.05 and tendencies at $P>0.05$ and $\leq 0.10$.

\section{RESULTS}

\section{Feed and Energy Intake}

Offering the high preweaning dietary plane (10 vs. 5 $\mathrm{L}$ of whole milk/d) resulted in greater milk intake $(7.7$ \pm 0.1 vs. $4.5 \pm 0.1 \mathrm{~L} / \mathrm{d}, P<0.001)$ and lower starter intake overall from wk 1 to $9(0.3 \pm 0.04$ vs. $0.7 \pm$
$0.04 \mathrm{~kg} / \mathrm{d}, P<0.001$; Figure 2a). Starter intake during the postweaning phase was not affected by preweaning $\operatorname{diet}(P=0.38)$, but it was greater from wk 11 to 25 in heifers offered the high postweaning diet compared with those offered the low postweaning $\operatorname{diet}(P<0.001$; Figure 2b).

The ME intake during the preweaning phase was affected by an interaction between preweaning plane and week of age $(P<0.0001)$. Heifers offered high preweaning diet had greater ME intake from wk 1 to 7 , but lower ME intake at wk $9(5.3 \pm 0.2$ vs. $6.6 \pm 0.2 \mathrm{Mcal} /$ $\mathrm{kg})$, than those offered the low preweaning $\operatorname{diet}(P<$ 0.001; Figure 2c). Preweaning diet did not influence ME intake during the postweaning phase $(P=0.41)$, but ME intake was greater from wk 11 to 25 in heifers offered the high postweaning plane compared with the those offered the low postweaning plane $(P<0.001$; Figure 2d).

\section{Growth and Feed Efficiency}

Overall BW averaged $39.1 \pm 0.6 \mathrm{~kg}$ at birth, 84.2 $\pm 1.3 \mathrm{~kg}$ at $9 \mathrm{wk}$, and $238.7 \pm 3.1 \mathrm{~kg}$ at $25 \mathrm{wk}$ of age. Body weight was not different among treatments at enrollment $(P=0.73)$. During the preweaning phase, BW was greater in heifers offered the high versus low
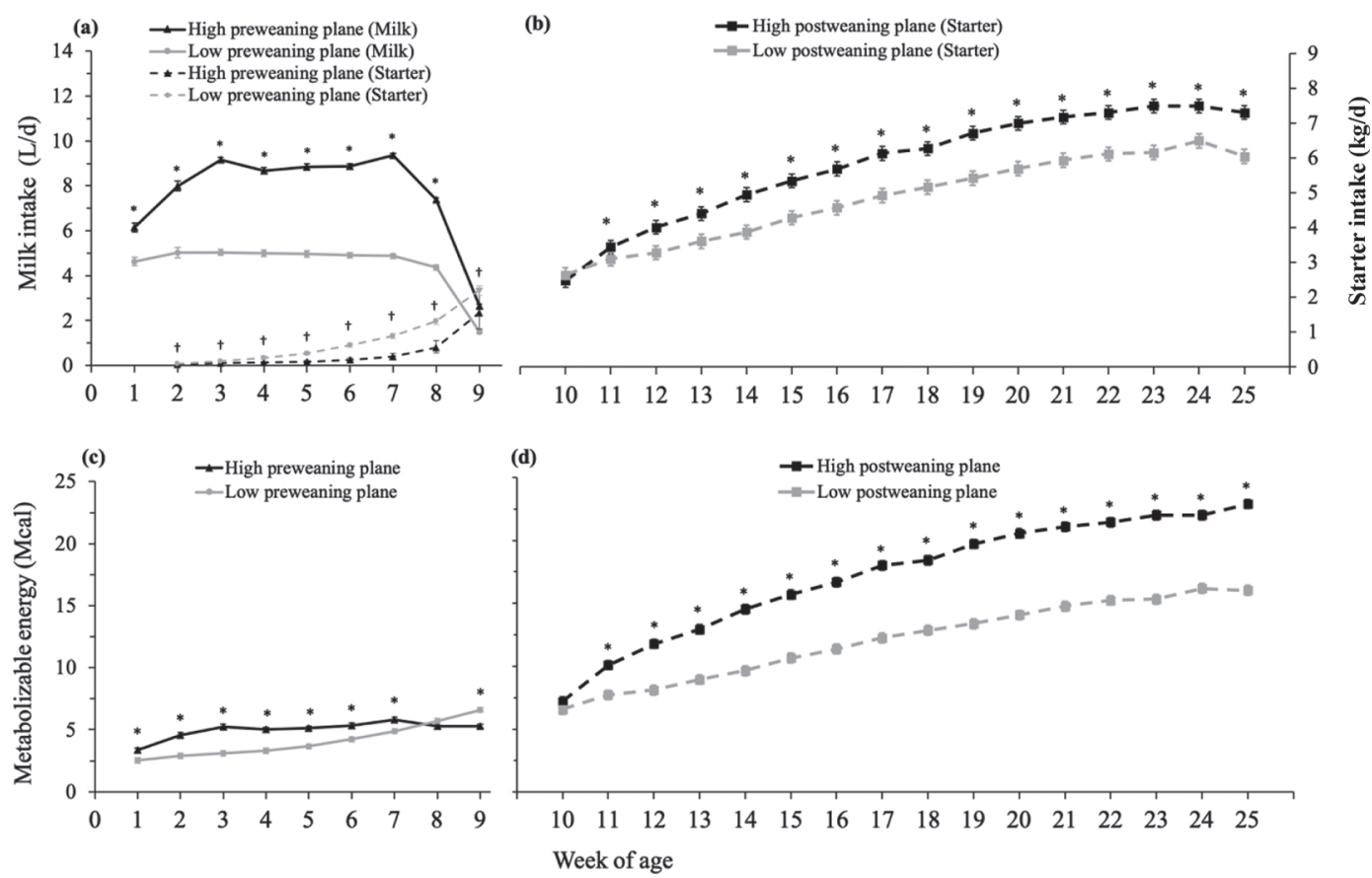

Figure 2. Effects of preweaning dietary plane of nutrition [high $(10 \mathrm{~L}$ of whole milk/d) vs. low (5 L of whole milk/d)] on milk (solid lines) and starter (dashed lines) intakes by 9 wk of age (panel a); effects of postweaning dietary plane of nutrition [high ( $85 \%$ of concentrate dry TMR) vs. low (70\% of concentrate dry TMR)] on starter intake from wk 10 to 25 (panel b); and effects of preweaning (panel c) and postweaning (panel d) dietary planes of nutrition on ME intake (Mcal) in Holstein heifers $(\mathrm{n}=36)$. Error bars represent SEM and are barely visible in panels c and d due to their small values. ${ }^{*}, \dagger$ Denote significant differences $(P \leq 0.05)$ between dietary groups at individual time points. 
preweaning diet (Figure 3a; $P<0.0001$ ). During the postweaning phase, BW was affected by both pre- $(P$ $=0.01)$ and postweaning diets $(P=0.01)$, as well as by the interaction between postweaning diet and week $(P=0.003)$. Heifers offered the high preweaning plane had greater BW at wk 10 (96.5 \pm 2.0 vs. $90.4 \pm 2.0 \mathrm{~kg}$; $P=0.04)$ and $11(102.6 \pm 2.1$ vs. $96.6 \pm 2.1 \mathrm{~kg} ; P=$ 0.04) than those offered the low preweaning plane (not shown). Heifers offered the high postweaning plane had greater BW from wk 16 to 25 than those offered the low postweaning plane (Figure $3 \mathrm{~b}$ ). Similarly, high preweaning diet heifers had greater heart girth during both the preweaning $(P<0.01$; Figure $3 \mathrm{c})$ and postweaning $(P=0.03$; not shown $)$ phases than low preweaning diet heifers. Heart girth during the postweaning phase was also greater in heifers offered the increased postweaning $\operatorname{diet}(P<0.01)$, which was evident at wk 16 and from wk 18 to 25 (Figure $3 \mathrm{~d}$ ). Compared with heifers receiving the low preweaning plane, those receiving the high preweaning plane had greater withers height from wk 6 to $9(P=0.05$; Figure $3 \mathrm{e})$ and from wk 14 to $16(P=$ 0.05 ; Figure $3 \mathrm{f})$. Withers height was not influenced by the postweaning plane $(P=0.20)$.

Preweaning daily ME intake $(P<0.001)$, ADG $(P<$ $0.001)$, and feed efficiency $(P=0.05)$ averaged in 1 and 2 mo of age were all positively influenced by offering the elevated preweaning plane of nutrition; yet, such differences were not consistent within different months for all
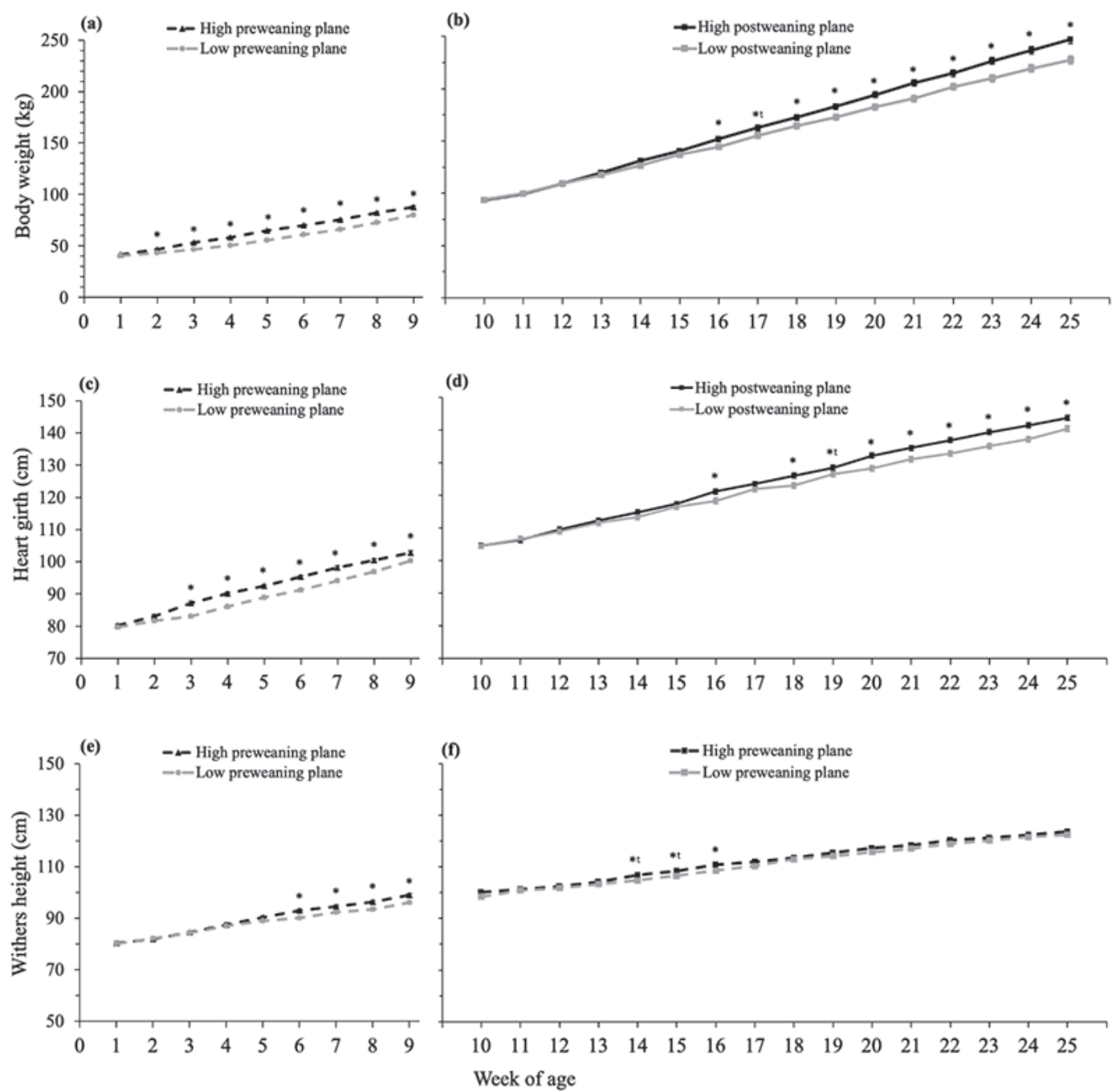

Figure 3. Effects of preweaning dietary plane of nutrition [high $(10 \mathrm{~L}$ of whole milk/d) vs. low (5 L of whole milk/d); dashed lines] or postweaning dietary plane of nutrition [high ( $85 \%$ of concentrate dry TMR) vs. low (70\% of concentrate dry TMR); solid lines] on body weight (panels a and b), heart girth (panels c and d), and withers height (panels e and $\mathrm{f}$ ) in Holstein heifers $(\mathrm{n}=36)$. In all panels, error bars representing SEM are barely visible due to their small values. ${ }^{*}$ Denotes significant differences $(P \leq 0.05)$ between dietary groups at individual weeks. ${ }^{* t}$ Denotes that dietary groups tended to differ $(0.05<P \leq 0.10)$ at individual weeks. 
of these variables (Table 2). No effects of preweaning plane were observed on the intake, growth, or the efficiency of growth when assessed in the postweaning phase (mo 3-6). However, postweaning daily ME intake $(P<0.001)$, ADG $(P=0.001)$, feed efficiency $(P<$ $0.01)$, and BCS $(P=0.04)$ were all increased in heifers offered the high compared with the low postweaning plane (Table 3).

\section{Insulin, IGF-1, Glucose, and BHB}

Circulating concentrations of IGF-1 were not different between treatments at wk 1, but were influenced by preweaning plane $(P<0.001)$, with IGF-1 concentrations being greater in heifers fed the high preweaning plane compared with those fed the low preweaning plane (overall concentration $101.6 \pm 3.6$ vs. $75.9 \pm$ $3.6 \mathrm{ng} / \mathrm{mL}$; Figure 4a). Overall, postweaning IGF-1 concentrations were greater in heifers offered the high postweaning plane compared with those offered the low plane $(178.0 \pm 4.8$ vs. $155.8 \pm 4.8 \mathrm{ng} / \mathrm{mL}, P<0.001$; Figure 4b).

Concentration of circulating insulin decreased over time during the preweaning phase $(P<0.001)$, but was not affected by the preweaning dietary plane $(P=$ 0.39 ; Figure 4c). During the postweaning phase, insulin concentration changed over time $(P=0.001)$ and was greater overall in heifers offered the high postweaning plane than those offered the low plane $(2.0 \pm 0.1$ vs. 1.8 $\pm 0.1 \mathrm{ng} / \mathrm{mL} ; P=0.04 ;$ Figure $4 \mathrm{~d})$.

Preweaning glucose concentration decreased from wk 1 through $9(P<0.01)$ and was greater overall $(118.8 \pm$ 2.9 vs. $110.1 \pm 2.9 \mathrm{mg} / \mathrm{dL} ; P=0.04)$ in heifers offered the high preweaning plane than those offered the low plane (Figure 4e). Interestingly, heifers offered the high preweaning plane had lower glucose concentration overall during the postweaning phase $(93.5 \pm 0.6$ vs. 95.8 $\pm 0.6 \mathrm{ng} / \mathrm{mL} ; P=0.01)$ than heifers offered the low preweaning plane. Postweaning dietary plane affected glucose concentrations in the postweaning phase, as heifers offered the high postweaning plane had greater glucose concentrations overall $(97.1 \pm 0.6$ vs. $92.1 \pm$ $0.6 \mathrm{ng} / \mathrm{mL} ; P<0.001)$ compared with those offered the low plane (Figure 4f).

During the preweaning phase, circulating BHB concentration increased at wk $9(P<0.001)$ and was greater beyond wk 7 in heifers offered the high preweaning plane compared with those offered the low plane $(P$ $<0.01$; Figure $4 \mathrm{~g}$ ). Heifers that received the high preweaning plane tended to have lower BHB concentration overall during the postweaning phase than heifers offered the low preweaning plane $(8.2 \pm 0.2$ vs. $8.7 \pm 0.2$ $\mathrm{ng} / \mathrm{mL} ; P=0.07)$. Postweaning BHB concentrations were greater $(8.8 \pm 0.2$ vs. $8.1 \pm 0.2 \mathrm{ng} / \mathrm{mL} ; P=0.01)$ in heifers offered the high postweaning plane compared with the low postweaning plane (Figure $4 \mathrm{~h}$ ).

\section{Volatile Fatty Acids Profile and Fecal Starch}

During the preweaning phase, heifers offered the high preweaning dietary plane had lower overall concentrations of ruminal acetic acid (29.7 \pm 1.1 vs. $33.5 \pm 1.1$ $\mathrm{m} M ; P=0.02)$, propionic acid $(11.2 \pm 0.7$ vs. $14.4 \pm$ $0.8 \mathrm{~m} M ; P<0.01)$, valeric acid $(0.6 \pm 0.1$ vs. $1.0 \pm 0.1$ $\mathrm{m} M ; P<0.01)$, and total VFA $(47.3 \pm 2.0$ vs. $55.6 \pm$ $2.1 \mathrm{~m} M ; P=0.01)$ than those offered the low preweaning plane. Results of VFA and fecal starch measured in monthly ruminal fluid samples during the preweaning phase are presented in Table 4 . There were significant interactions between preweaning dietary plane and month of age in ruminal butyric acid and caproic acid assessed during the postweaning phase. At 3 mo of age, both butyric and caproic acid were reduced in heifers offered the high preweaning plane compared with the

Table 2. Effects of offering different preweaning planes of nutrition on daily ME intake, ADG, feed efficiency (FE; ME per kilogram of daily gain), and BCS averaged at 1 and 2 mo of age in 36 Holstein heifers

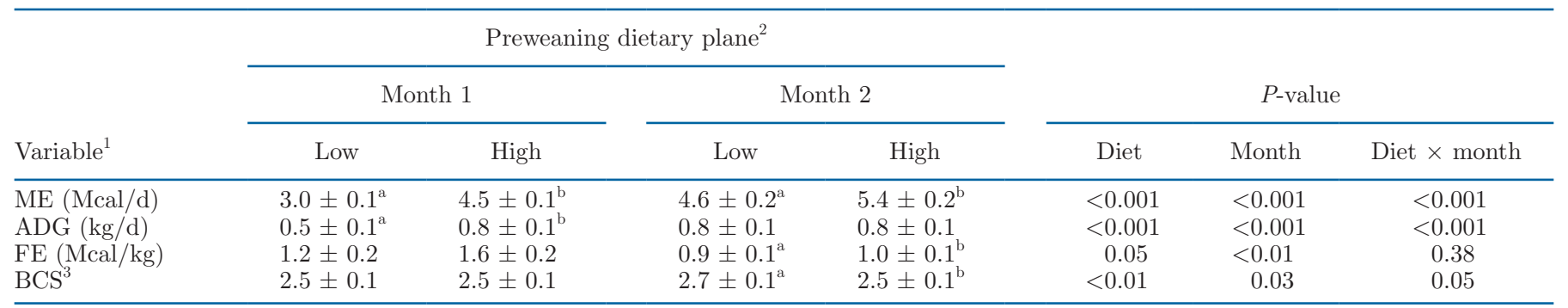

$\overline{\mathrm{a}, \mathrm{b}}$ Values in the same row with differing superscripts differ $(P \leq 0.05)$ between preweaning dietary plane at individual months $($ Diet $\times$ month $)$. ${ }^{1}$ Values are presented as LSM \pm SEM.

${ }^{2}$ Preweaning dietary plane of nutrition: low $=5 \mathrm{~L}$ of pasteurized whole milk over 2 meals per day from wk 1 to 7 of age $(\mathrm{n}=18)$; high $=10 \mathrm{~L}$ of pasteurized whole milk over 4 meals per day from wk 1 to 7 of age $(\mathrm{n}=18)$.

${ }^{3} \mathrm{BCS}$ measured on a scale from 1 to 5 . 
low plane (Table 5). During the postweaning phase, offering the high postweaning plane increased ruminal concentrations of acetic $(P=0.05)$, propionic $(P<$ $0.001)$, butyric $(P<0.001)$, valeric $(P<0.001)$, and caproic acids $(P<0.01)$, as well as total VFA concentrations $(P<0.001)$ compared with offering the low postweaning plane (Table 6).

\section{DISCUSSION}

There is currently a paucity of data regarding postweaning planes of nutrition during the initial months following weaning, despite this period being critical in heifer management and development (Overton et al., 2013). Therefore, the objective of the present study was to characterize how plane of nutrition during the pre- and postweaning periods affects heifer growth and development. Overall, the results indicate that feeding a high plane of nutrition in both the pre- and postweaning periods increases indicators of heifer growth and development; however, minimal interactions between pre- and postweaning planes of nutrition existed in the present study. We hypothesized that when differing planes of nutrition were offered in the preweaning phase, the influence of postweaning diets on overall development would be dependent on the previously offered diet. Rather, the results revealed that differences in growth and development parameters were explained largely by differences in the preweaning or postweaning phases, regardless of the diet offered preweaning.

Several factors may have contributed to the lack of interaction between the 2 phases. First, there have been numerous studies indicating that when calves are fed more milk preweaning via automated feeders or manual feedings, large growth depression occurs if weaned before 8 wk of age (de Passillé et al., 2011; Eckert et al., 2015; Meale et al., 2015). In the present study, the weaning transition began at $7 \mathrm{wk}$, and weaning was completed at 9 wk of life, which is later than studies that characterized growth depression, reduced fiber digestion, and reduced feed efficiency postweaning after elevated levels of milk were fed preweaning (Hill et al., 2016; Dennis et al., 2018; Quigley et al., 2018). Second, the weaning transition occurred gradually, with calves weaned over $10 \mathrm{~d}$ by a $10 \%$ reduction in milk volume per day. This gradual weaning may have allowed for sufficient adaptation to the reduction in milk. Previous research (Sweeney et al., 2010) has demonstrated that a 10-d weaning transition in calves fed high planes of nutrition preweaning is optimal compared with other weaning methods (i.e., weaning abruptly or weaning over $4 \mathrm{~d}$ or $22 \mathrm{~d}$ ) from a production standpoint. Furthermore, the 10-d stepdown reduction in milk 


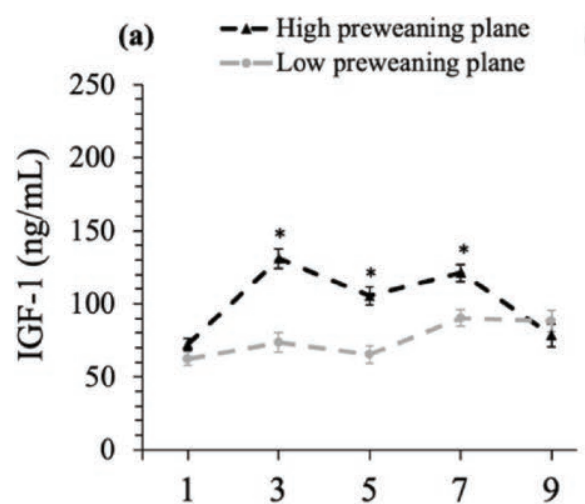

(b) $\quad \rightarrow$ High postweaning plane

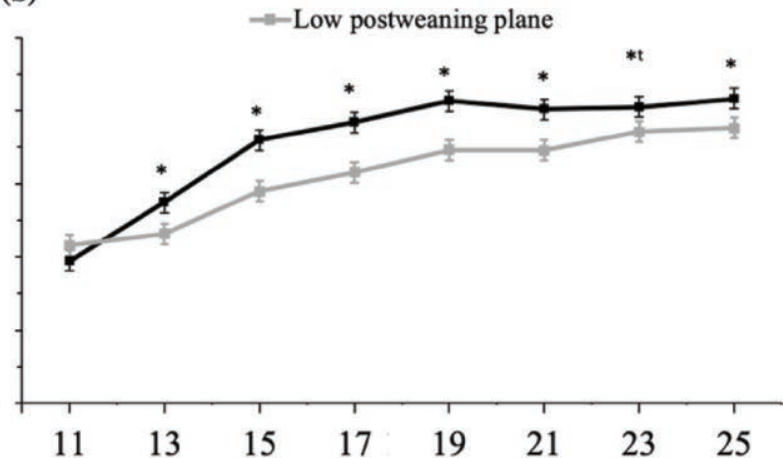

(c)

(d)
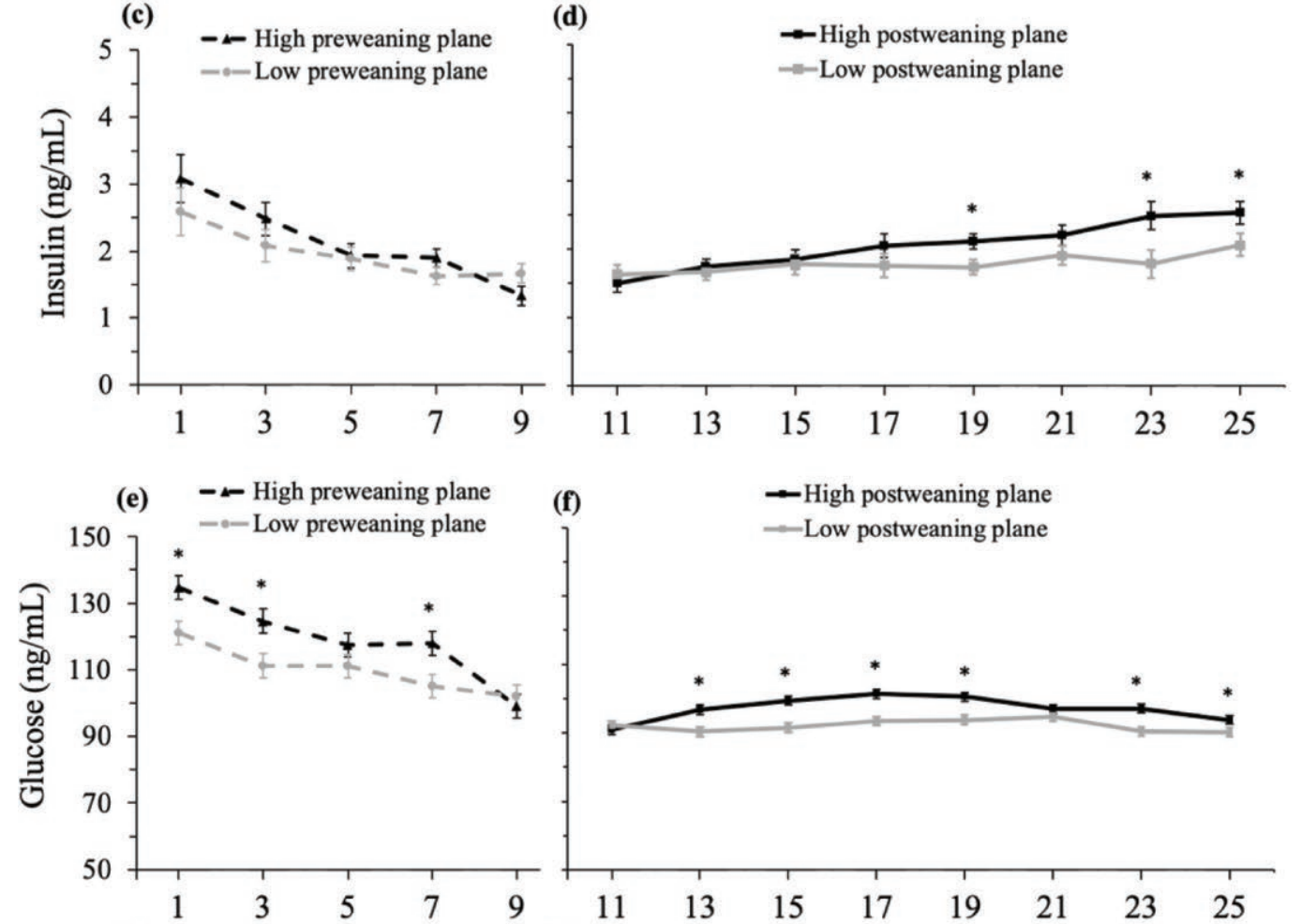

(g)

(h)
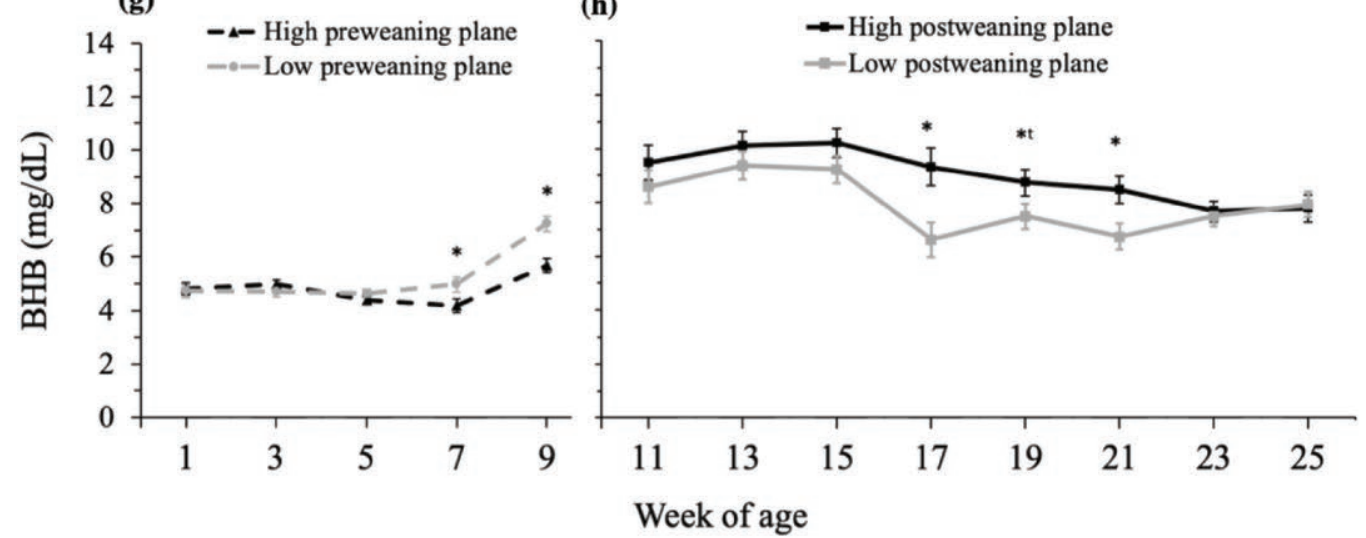

Figure 4. Effects of preweaning dietary plane of nutrition [high $(10 \mathrm{~L}$ of whole milk/d) vs. low (5 L of whole milk); dashed lines] or postweaning dietary plane of nutrition [high ( $85 \%$ of concentrate dry TMR) vs. low ( $70 \%$ of concentrate dry TMR); solid lines] on concentrations of circulating insulin growth factor-1 (IGF-1; panels a and b), insulin (panels c and d), glucose (panels e and f), and BHB (panels g and h) in Holstein heifers $(\mathrm{n}=36)$. In all panels, error bars represent SEM. *Denotes significant differences $(P \leq 0.05)$ between dietary groups at individual weeks. ${ }^{* t}$ Denotes that dietary groups tended to differ $(0.05<P \leq 0.10)$ at individual weeks. 
Table 4. Effects of offering different preweaning planes of nutrition on ruminal VFA ( $\mathrm{m} M)$ and fecal starch (\%) concentrations during the preweaning phase in Holstein heifers $(\mathrm{n}=36)$

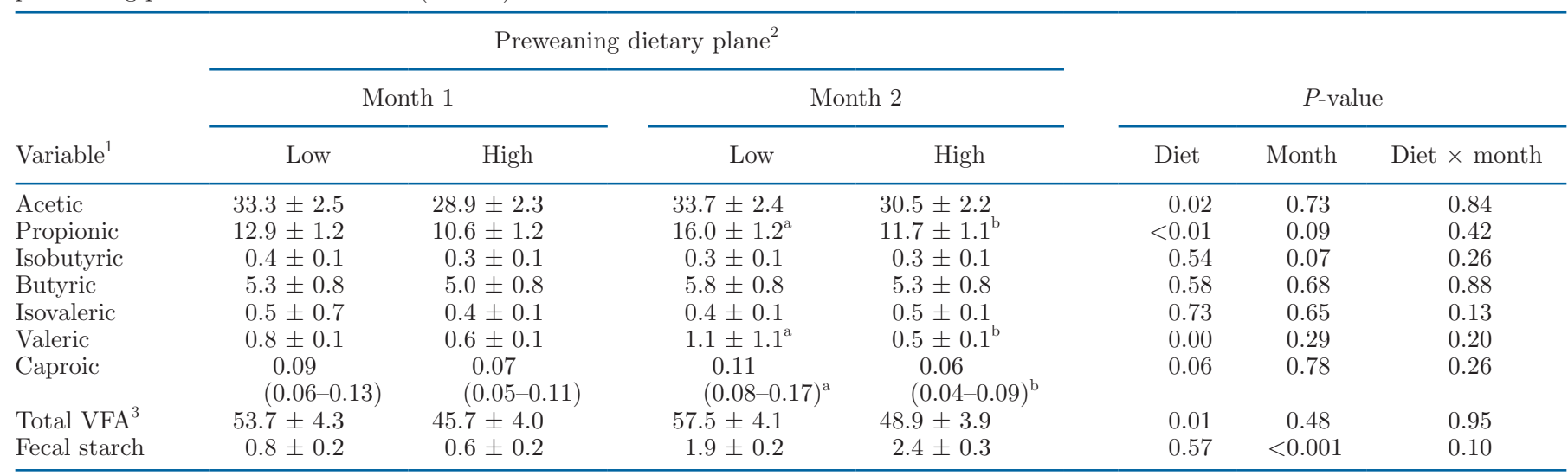

${ }_{\mathrm{a}, \mathrm{b}}$ Values in the same row with differing superscripts differ $(P \leq 0.05)$ between preweaning dietary plane at individual months (Diet $\times$ month). ${ }^{1}$ Values are presented as LSM \pm SEM for all variables except for caproic acid, which are presented as the back-transformed LSM and respective $95 \%$ CI.

${ }^{2}$ Preweaning dietary plane of nutrition: low $=5 \mathrm{~L}$ of pasteurized whole milk over 2 meals per day from wk 1 to 7 of age $(\mathrm{n}=18)$; high $=10 \mathrm{~L}$ of pasteurized whole milk over 4 meals per day from wk 1 to 7 of age $(\mathrm{n}=18)$.

${ }^{3}$ Overall total VFA differed between preweaning dietary groups (low $=55.6 \pm 2.1 \mathrm{~m} M$; high $=47.3 \pm 2.0 \mathrm{~m} M ; P=0.01$ ), but such difference was not significant $(P>0.05)$ when assessed by individual months.

availability $(10 \% / d)$ in the present study was greater than that implemented by Sweeney et al. (2010). The changes in intake (Strzetelski et al., 2001; Hill et al., 2006 a,b, 2010) and BW (Bar-Peled et al., 1997; Jasper and Weary, 2002; Cowles et al., 2006) commonly characterized throughout the weaning phase, as affected by the preweaning diet, were not evident in this study. This suggests that the 10-d stepdown weaning transition was sufficient to avoid depressed weaning and postweaning performance and may explain the lack of interaction between pre- and postweaning diets. Third, the allowance of ad libitum starter access for both treatment groups in the preweaning phase led to a lack of differences in energy intake between treatment groups during the final weeks of the preweaning period, and thus high rates of growth and similar ME intakes, especially after weaning. Similarly, both low and high postweaning dietary planes were also relatively high in both protein and energy compared with previous studies (Brown et al., 2005; Davis Rincker et al., 2008a), allowing for some of the highest recorded ADG in both dietary treatment groups for heifers of this age. In summary, interactions between planes of nutrition offered during the pre- and postweaning phases might have been found with an early or abrupt weaning transition, or with greater differences between the energy content of the pre- and postweaning diets. Given the lack of interaction between the 2 phases in the current study, discussion from this point forward will focus on the pre- and postweaning periods separately.

\section{Effects of Preweaning Plane of Nutrition}

In the present study, growth and intake responses to feeding a high plane of milk nutrition during the preweaning period were consistent with previous studies that have reported improved growth during early life through increased whole milk or milk-replacer provision (Diaz et al., 2001; Jasper and Weary, 2002; Brown et al., 2005). High preweaning plane calves had increased ADG during the first month of life, gaining approximately an additional $300 \mathrm{~g} / \mathrm{d}$ compared with low plane calves, likely due to increased milk allowance and numerically comparable starter intake during this period. However, differences in starter intake were observed during the first 2 mo of life, with low preweaning plane calves having greater starter intake than high plane calves, which has been consistently reported across studies in calves fed restricted levels of milk (Jasper and Weary, 2002; Terré et al., 2007). Despite this, ME intake remained greater in high preweaning plane calves during the first 2 mo of life compared with low plane calves. It is important to note that differences in ME intake were greatest during the first month of life (4.5 vs. $3.0 \mathrm{Mcal} / \mathrm{d}$ ) when starter intake was negligible and supplied a small proportion of energy intake. This suggests that even if milk intake is restricted during the first month of life, starter intake remains low and cannot be consumed in sufficient quantities to compensate for the depressed ME intake compared with calves fed elevated levels of milk. 

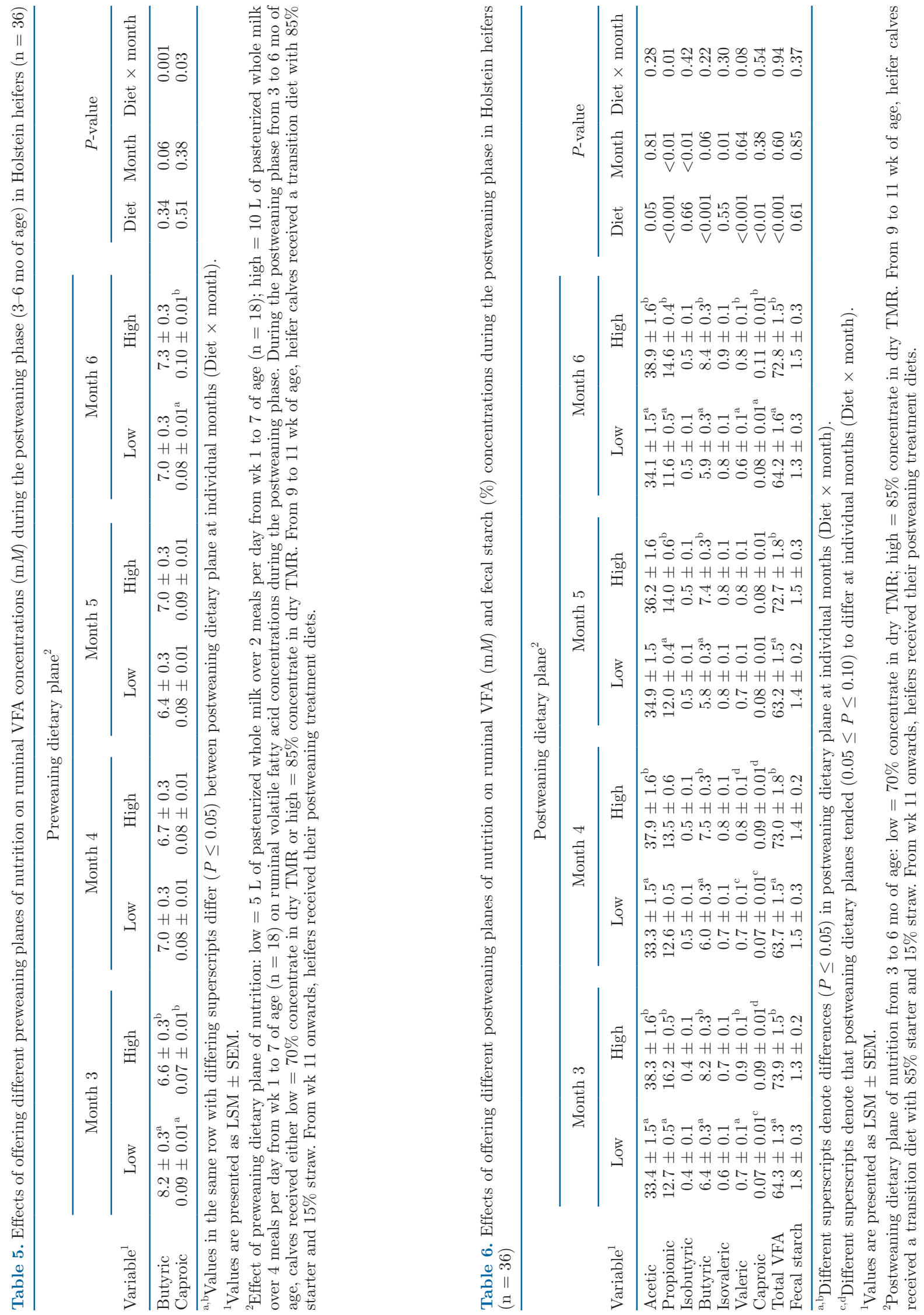
The somatotropic axis, consisting of growth hormone, IGF-1, IGF-2, and their associated carrier proteins and receptors (Renaville et al., 2002), is the primary regulator of growth and development in cattle (Hammon and Blum, 1997; Hammon et al., 2000). Previous research has demonstrated that increasing nutrient intake from milk replacer (Bartlett et al., 2006; Daniels et al., 2008; Schaff et al., 2016) and whole milk (Haisan et al., 2018) stimulates IGF-1 secretion and increases serum IGF-1 concentrations in calves. In agreement with previous work, the present study demonstrated that circulatory IGF-1 concentrations followed the pattern of ME intake between treatments, with high preweaning plane calves having greater serum IGF-1 concentrations at wk 3, 5 , and 7 compared with low preweaning plane calves. Furthermore, differences in IGF-1 concentrations were greatest at $3 \mathrm{wk}$ of life, when ME intake differences were greatest. Increased circulating IGF-1 in high preweaning plane calves was associated with greater BW, heart girth, and wither height, with differences beginning at wk 2,3 , and 6 , respectively. The observed relationships between circulating IGF-1 and growth parameters supports the notion that IGF-1 is a key regulator of growth and development in young calves.

Preweaned ruminants are essentially considered pseudomonogastric, and thus glucose is the main energy substrate during this time (Drackley, 2008). Due to their increased milk allowance, calves offered the high preweaning plane had elevated milk, and thus lactose intake, throughout the preweaning phase; subsequently, they had higher glucose concentrations at wk 3,5 , and 7 compared with calves offered the low plane, which is in agreement with previous studies (Hugi et al., 1997; Bach et al., 2013; Yunta et al., 2015; MacPherson et al., 2016). Factors influencing plasma glucose concentrations include feed intake, liver gluconeogenesis, and catabolism of glycogen stores (Aronoff et al., 2004). Therefore, although all calves were offered $2.5 \mathrm{~L}$ of whole milk $3 \mathrm{~h}$ before sampling time, the calves fed the high preweaning plane may have been able to store excess amounts as glycogen compared with those offered the low plane. Despite glucose concentrations being greater in high preweaning plane calves, no differences in insulin concentrations were observed. Although in contrast to previous studies (Hugi et al., 1997; Bach et al., 2013; Yunta et al., 2015; MacPherson et al., 2016), this result was expected due to the meal allowance for all calves before sampling time, as described previously. If the sampling time was shifted to $3 \mathrm{~h}$ following the second daily feeding, in which high preweaning plane heifers received $2.5 \mathrm{~L}$ of milk and low preweaning plane heifers did not receive any milk, differences in insulin concentrations would likely have been observed. Furthermore, insulin is not only regulated by feed intake, but also by age, diet, and hormones that control abomasal emptying (MacPherson et al., 2016; Stahel et al., 2017). The multitude of factors influencing circulating insulin concentrations results in high variability, especially during the preweaning period.

It is important to note that heifers offered the low preweaning plane were not able to compensate for reduced milk allowance and only achieved equivalent ME intake to heifers offered the high plane at the end of the preweaning period. However, similar ADG $(\sim 800 \mathrm{~g} / \mathrm{d})$ between high and low preweaning plane groups was observed during the second month of life, likely due to greater starter intake and gastrointestinal adaptation to the dry diet in the low preweaning plane group as weaning approached. Previous research has indicated increased feed efficiency in calves offered elevated preweaning planes of nutrition (Brown et al., 2005; Bartlett et al., 2006). However, in the present study, high preweaning plane heifers had no efficiency advantage during the first month of life and were actually less efficient than low plane heifers during the second month. This result is unexpected; however, it may be due to the elevated solid-feed intake during the preweaning period increasing gastrointestinal development to improve efficiency to concentrate diets toward weaning.

The transition from a functional pseudomonogastric, largely dependent on a liquid diet, to a functional ruminant requires significant development of the rumen. During the preweaning phase, total VFA was greater in low preweaning plane heifers, with propionic acid in ruminal fluid being the most responsive to the preweaning diet, especially during the second month of life. No differences were detected in ruminal butyrate, the precursor for ruminal ketogenesis. It is important to note that measurements of VFA were performed only once every month in the present study; therefore, it is possible that weekly variations in specific VFA concentrations as a result of starter intake were not detected. Despite this, circulatory BHB, which is produced by the rumen epithelium in response to absorption of butyrate (Quigley et al., 1991), was greater in low preweaning plane heifers. The use of blood BHB as a tool to evaluate starter consumption in calves has been confirmed in additional studies (Omidi-Mirzaei et al., 2015; Overvest et al., 2016; Deelen et al., 2016) and the elevated concentrations of BHB in low preweaning plane heifers during wk 7 and 9 in the current study support this finding. To evaluate the effects of preweaning plane of nutrition on hindgut function and development, the present study measured fecal starch percentage, in which no effect of preweaning diet was observed. Although fecal starch increased from the first to second month of life, levels were relatively low in this experiment, suggesting that 
starch was digested and absorbed at a high rate with no indication of hindgut acidosis. This finding may reflect the low starch content of the calf starter in comparison to other studies. However, there is currently a large range in the values of starch and rapidly fermentable carbohydrates in commercial calf starters, and further research is needed to determine how starch content of calf starter should be tailored for specific preweaning milk feeding strategies.

\section{Effects of Postweaning Plane of Nutrition}

After adapting to the postweaning diet, and beginning at the fourth month of life, there were marked increases in indicators of growth and development in calves offered the high postweaning plane compared with those offered the low plane. Specifically, total ME and solid-feed intake began to diverge between postweaning plane groups at wk 11 and remained high for the duration of the study. Although no differences were observed in circulatory IGF-1 at wk 11, concentrations were greater in high postweaning plane heifers at wk 13 and, similar to ME intake, remained elevated throughout the study, in agreement with previous reports (Smith et al., 2002; Brown et al., 2005). This result suggests that an immediate and short-term increase in ME intake is not sufficient to stimulate IGF-1 production and that sustained IGF-1 production may only occur when ME intake increases for a longer period of time (i.e., 1-2 wk). In terms of glucose concentrations, the results demonstrated that glucose sharply decreased in both treatments after weaning (wk 9), but at wk 11, glucose concentrations were greater for the high than for the low postweaning plane group and were greater for the duration of the postweaning period. Similar to the preweaning period, no differences in insulin concentrations were observed between postweaning dietary treatments for the majority of the postweaning period. However, at wk 19, heifers offered the high postweaning plane had greater circulating insulin concentrations than those offered the low plane. The increase in insulin concentrations occurred $6 \mathrm{wk}$ after the increase in circulating IGF-1, and stimulation of insulin production during the postweaning period may occur independently of ME intake, unlike IGF-1. The increase in circulating insulin and unchanged blood glucose in high postweaning plane heifers throughout the postweaning period may indicate a reduction in insulin sensitivity, which is commonly reported during the postweaning phase (Pantophlet et al., 2016).

The increased blood indicators of energy status during the postweaning period were matched by increased total VFA in heifers offered the high postweaning plane, specifically in acetic acid, butyric acid, and propionic acid. The rise in propionic acid may contribute to the rise in blood glucose concentrations in high postweaning heifers, given its use as a substrate in liver gluconeogenesis; yet, other VFA are used as energy substrates and likely spare glucose utilization in heifers fed after weaning (Benschop and Cant, 2009). Furthermore, although ruminal butyrate was consistently increased in high postweaning plane heifers, circulating BHB was only greater from wk 17 to 21 . The increase in BHB during these weeks can be accounted for by the mass conversion of ruminal butyrate to BHB within the rumen epithelium (Steele et al., 2011). In summary, increased total and specific VFA concentrations, in combination with the notably low levels of fecal starch, may reflect both the starch and fiber levels of the dry diet, as well as the smooth transition to the postweaning diet. These low levels of fecal starch and smooth weaning transition may have led to greater capacity for forestomach starch digestion compared with other studies that weaned calves abruptly and report elevated fecal starch during the weeks and months following weaning (Quigley et al., 2018; van Niekerk et al., 2020).

In comparison to previous studies investigating postweaning nutrition, the overall feed and calorie intake in the present study was greater (Brown et al., 2005; Davis Rincker et al., 2008a; van Niekerk et al., 2020), and in a specific instance, the growth and intake results were double those reported previously (Petitclerc et al., 1999). Despite the present study reporting such high growth rates $(1.5-1.6 \mathrm{~kg} / \mathrm{d}$ from mo 4-6) during the postweaning period, the overall ADG remained elevated and IGF-1 concentrations increased as heifers progressed until wk 19, remaining constant throughout the postweaning phase. It is possible that increased signaling of growth mediators, especially IGF-1, in the present study contributed to improved development and support enhanced growth - a key example being improved reproductive development in heifers offered the increased postweaning dietary plane (Bruinjé et al., 2019; Bruinjé et al., 2020 in review).

Indicators of development were increased during the postweaning period; however, it is important to note that ME intake per kilogram of gain was greater in high postweaning plane heifers during specific months, and increased greatly throughout the remainder of the postweaning period for both treatments. The reduction in feed efficiency for both postweaning treatments, but especially the high postweaning plane group, may be related to decreased energy utilization, as demonstrated by the increase in blood insulin in the last weeks of the experiment while glucose concentrations were unchanged. Despite this decrease in feed efficiency, high postweaning plane heifers had higher BW from wk 16 onwards, and higher BCS than low postweaning plane 
heifers during mo 4 and 5 , yet no differences were observed during mo 6 . In both treatments, BCS increased with time, suggesting that more dietary energy is being converted to fat at the expense of lean tissue growth, which may be a concern during the prepubertal period when allometric growth of the mammary gland occurs (Geiger et al., 2016; Geiger, 2019). Previous research has hypothesized that over-conditioning heifers during the months following weaning may cause an accumulation of fat in the mammary fat pad instead of parenchymal tissue growth (Davis Rincker et al., 2008b). However, the relationship between mammary gland fat deposition during the pre- and postpubertal periods in calves with accelerated growth rates, as well as any potential long-term effects on mammary physiology and milk production, require further investigation.

\section{CONCLUSIONS}

Planes of nutrition with differing energy levels in the pre- and postweaning phases affected several indicators of heifer development. Increasing the preweaning plane of nutrition increased growth and energy intake, but these effects were not maintained during the postweaning phase. For most indicators, no interaction was observed between pre- and postweaning planes of nutrition, indicating that differences in intake, growth, and select metabolite and hormone concentrations resulting from differing preweaning planes of nutrition may have little influence in the postweaning phase. Increasing the postweaning plane of nutrition increased growth and energy intake, independent of the preweaning planes of nutrition. Increases in glucose, insulin, IGF-1, and BHB concentrations were noted for heifers receiving increased planes of nutrition during both the pre- and postweaning phases.

\section{ACKNOWLEDGMENTS}

The authors thank Alberta Agriculture and Forestry (Edmonton, AB, Canada) for providing the funding for this project and Trouw Nutrition (Guelph, ON, Canada) for donating the feed. M. A. Steele's position was supported by Alberta Milk (Edmonton, AB, Canada), BC Dairy Association (Burnaby, BC, Canada), Dairy Farmers of Manitoba (Winnipeg, MB, Canada), Lallemand Animal Nutrition (Montreal, QC, Canada), Trouw Animal Nutrition (Guelph, ON, Canada), SaskMilk (Regina, SK, Canada), Westgen (Abbotsford, BC, Canada), and National Science and Engineering Research Council (Ottawa, ON, Canada). The authors have not stated any conflicts of interest.

\section{REFERENCES}

AOAC International. 2000. Official Methods of Analysis. 17th ed. Assoc. Off. Anal. Chem., Arlington, VA.

Aronoff, S. L., K. Berkowitz, B. Shreiner, and L. Want. 2004. Glucose metabolism and regulation: Beyond insulin and glucagon. Diabetes Spectr. 17:183-190. https://doi.org/10.2337/diaspect.17.3.183.

Bach, A. 2011. Associations between several aspects of heifer development and dairy cow survivability to second lactation. J. Dairy Sci. 94:1052-1057. https://doi.org/10.3168/jds.2010-3633.

Bach, A., L. Domingo, C. Montoro, and M. Terré. 2013. Short communication: Insulin responsiveness is affected by the level of milk replacer offered to young calves. J. Dairy Sci. 96:4634-4637. https: //doi.org/10.3168/jds.2012-6196.

Bar-Peled, U., B. Robinzon, E. Maltz, H. Tagari, Y. Folman, I. Bruckental, H. Voet, H. Gacitua, and A. R. Lehrer. 1997. Increased weight gain and effects on production parameters of Holstein heifer calves that were allowed to suckle from birth to six weeks of age. J. Dairy Sci. 80:2523-2528. https://doi.org/10.3168/jds.S0022 -0302(97)76205-2.

Bartlett, K. S., F. K. McKeith, M. J. VandeHaar, G. E. Dahl, and J. K. Drackley. 2006. Growth and body composition of dairy calves fed milk replacers containing different amounts of protein at two feeding rates. J. Anim. Sci. 84:1454-1467. https://doi.org/10 $.2527 / 2006.8461454 x$.

Benschop, D. L., and J. P. Cant. 2009. Developmental changes in clearance of intravenous doses of glucose, acetate and B-hydroxybutyrate from plasma of calves. Livest. Sci. 122:177-185. https:// doi.org/10.1016/j.livsci.2008.08.011.

Bielmann, V., J. Gillan, N. R. Perkins, A. L. Skidmore, S. Godden, and K. E. Leslie. 2010. An evaluation of Brix refractometry instruments for measurement of colostrum quality in dairy cattle. J. Dairy Sci. 93:3713-3721. https://doi.org/10.3168/jds.2009-2943.

Brown, E. G., M. J. VandeHaar, K. M. Daniels, J. S. Liesman, L. T. Chapin, D. H. Keisler, and M. S. Weber Nielsen. 2005. Effect of increasing energy and protein intake on body growth and carcass composition of heifer calves. J. Dairy Sci. 88:585-594. https://doi .org/10.3168/jds.S0022-0302(05)72722-3.

Bruinjé, T. C., J. P. Rosadiuk, F. Moslemipur, J. E. Carrelli, M. A. Steele, and D. J. Ambrose. 2019. Carryover effects of pre- and post-weaning planes of nutrition on reproductive tract development and estrous cycle characteristics in Holstein heifers. J. Dairy Sci. 102:10514-10529. https://doi.org/10.3168/jds.2019-16249.

Bruinjé, T. C., J. P. Rosadiuk, F. Moslemipur, H. Sauerwein, M. A. Steele, and D. J. Ambrose. 2020. Differing planes of pre- and postweaning phase nutrition in Holstein heifers: II. Effects on circulating leptin, luteinizing hormone, and age at puberty. J. Dairy Sci. 104:1153-1163. https://doi.org/10.3168/jds.2020-18810.

Capuco, A. V., and R. M. Akers. 2010. Management and environmental influences on mammary gland development and milk production. Pages 259-292 in Managing the Prenatal Environment to Enhance Livestock Productivity. P. L. Greenwood, A. W. Bell, P. E. Vercoe and G. J. Viljoen, ed. Springer Science and Business Media B. V., Dordrecht, the Netherlands.

Chelikani, P. K., D. J. Ambrose, D. H. Keisler, and J. J. Kennelly. 2009. Effects of dietary energy and protein density on plasma concentrations of leptin and metabolic hormones in dairy heifers. J. Dairy Sci. 92:1430-1441. https://doi.org/10.3168/jds.2008-1385.

Cowles, K. E., R. A. White, N. L. Whitehouse, and P. S. Erickson. 2006. Growth characteristics of calves fed an intensified milk replacer regimen with additional lactoferrin. J. Dairy Sci. 89:48354845. https://doi.org/10.3168/jds.S0022-0302(06)72532-2.

Daniels, K. M., S. R. Hill, K. F. Knowlton, R. E. James, M. L. McGilliard, and R. M. Akers. 2008. Effects of milk replacer composition on selected blood metabolites and hormones in preweaned Holstein heifers. J. Dairy Sci. 91:2628-2640. https://doi.org/10.3168/ jds.2007-0859.

Davis Rincker, L. E., M. J. Vandehaar, C. A. Wolf, J. S. Liesman, L. T. Chapin, and M. S. Weber Nielsen. 2011. Effect of intensified feeding of heifer calves on growth, pubertal age, calving age, milk 
yield, and economics. J. Dairy Sci. 94:3554-3567. https://doi.org/ $10.3168 /$ jds.2010-3923.

Davis Rincker, L. E., M. S. Weber Nielsen, L. T. Chapin, J. S. Liesman, and M. J. Vandehaar. 2008a. Effects of feeding prepubertal heifers a high-energy diet for three, six, or twelve weeks on feed intake, body growth, and fat deposition. J. Dairy Sci. 91:1913-1925. https://doi.org/10.3168/jds.2006-210.

Davis Rincker, L. E., M. S. Weber Nielsen, L. T. Chapin, J. S. Liesman, K. M. Daniels, R. M. Akers, and M. J. Vandehaar. 2008b. Effects of feeding prepubertal heifers a high-energy diet for three, six, or twelve weeks on mammary growth and composition. J. Dairy Sci. 91:1926-1935. https://doi.org/10.3168/jds.2006-211.

de Passillé, A. M., T. F. Borderas, and J. Rushen. 2011. Weaning age of calves fed a high milk allowance by automated feeders: Effects on feed, water and energy intake, behavioural signs of hunger, and weight gains. J. Dairy Sci. 94:1401-1408. https://doi.org/10.3168/ jds.2010-3441.

Deelen, S. M., K. E. Leslie, M. A. Steele, E. Eckert, H. E. Brown, and T. J. DeVries. 2016. Validation of a calf-side $\beta$-hydroxybutyrate test and its utility for estimation of starter intake in dairy calves around weaning. J. Dairy Sci. 99:7624-7633. https://doi.org/10 $.3168 / j d s .2016-11097$.

Dennis, T. S., F. X. Suarez-Mena, T. M. Hill, J. D. Quigley, R. L. Schlotterbeck, and L. Hulbert. 2018. Effect of milk replacer feeding rate, age at weaning, and method of reducing milk replacer to weaning on digestion, performance, rumination, and activity in dairy calves to 4 months of age. J. Dairy Sci. 101:268-278. https:/ /doi.org/10.3168/jds.2017-13692.

Diaz, M. C., M. E. Van Amburgh, J. M. Smith, J. M. Kelsey, and E. L. Hutten. 2001. Composition of growth of Holstein calves fed milk replacer from birth to 105- kilogram body weight. J. Dairy Sci. 84:830-842. https://doi.org/10.3168/jds.S0022-0302(01)74541-9.

Drackley, J. K. 2008. Calf nutrition from birth to breeding. Vet. Clin. North Am. Food Anim. Pract. 24:55-86. https://doi.org/10.1016/ j.cvfa.2008.01.001.

Eckert, E., H. E. Brown, K. E. Leslie, T. J. DeVries, and M. A. Steele. 2015. Weaning age affects growth, feed intake, gastrointestinal development, and behaviour in Holstein calves fed an elevated plane of nutrition during the preweaning stage. J. Dairy Sci. 98:63156326. https://doi.org/10.3168/jds.2014-9062.

Geiger, A. J. 2019. Review: The pre-pubertal bovine mammary gland: Unlocking the potential of the future herd. Animal 13(S1):s4-s10. https://doi.org/10.1017/S1751731119001204.

Geiger, A. J., R. E. James, C. L. Parsons, A. V. Capuco, and R. M. Akers. 2015. Enhanced pre-weaning nutrition stimulates mammary gland development in dairy heifer calves. J. Dairy Sci. 98:405.

Geiger, A. J., C. L. M. Parsons, and R. M. Akers. 2016. Feeding a higher plane of nutrition and providing exogenous estrogen increases mammary gland development in Holstein heifer calves. J. Dairy Sci. 99:7642-7653. https://doi.org/10.3168/jds.2016-11283.

Geishauser, T. 1993. An instrument for the collection and transfer of ruminal fluid and for the administration of water-soluble drugs in adult cattle. Bov. Pract. 27:38-42.

Haisan, J., M. Oba, D. J. Ambrose, and M. A. Steele. 2018. Short communication: The effects of offering a high or low plane of milk preweaning on insulin-like growth factor and insulin-like growth factor binding proteins in dairy heifer calves. J. Dairy Sci. 101:1144111446. https://doi.org/10.3168/jds.2017-14339.

Hall, M. B. 2009. Determination of starch, including maltooligosaccharides, in animal feeds: Comparison of methods and a method recommended for AOAC collaborative study. J. AOAC Int. 92:42-49. https://doi.org/10.1093/jaoac/92.1.42.

Hammon, H., and J. W. Blum. 1997. The somatotropic axis in neonatal calves can be modulated by nutrition, growth hormone and Long-R3-IGF-I. Am. J. Physiol. 273:E130-E138. https://doi.org/ 10.1152/ajpendo.1997.273.1.E130.

Hammon, H. M., I. A. Zanker, and J. W. Blum. 2000. Delayed colostrum feeding affects IGF-I and insulin plasma concentrations in neonatal calves. J. Dairy Sci. 83:85-92. https://doi.org/10.3168/ jds.S0022-0302(00)74859-4.
Heinrichs, A. J., C. M. Jones, S. M. Gray, P. A. Heinrichs, S. A. Cornelisse, and R. C. Goodling. 2013. Identifying efficient dairy heifer producers using production costs and data envelopment analysis. J. Dairy Sci. 96:7355-7362. https://doi.org/10.3168/jds.2012-6488.

Hill, T. M., J. M. Aldrich, R. L. Schlotterbeck, and H. G. Bateman II.. 2006a. Effects of feeding calves different rates and protein concentrations of twenty percent fat milk replacers on growth during the neonatal period. Prof. Anim. Sci. 22:252-260. https://doi.org/10 $.15232 /$ S1080-7446(15)31101-3.

Hill, T. M., J. M. Aldrich, R. L. Schlotterbeck, and H. G. Bateman II.. 2006b. Effects of feeding rate and concentrations of protein and fat of milk replacers fed to neonatal calves. Prof. Anim. Sci 22:374-381. https://doi.org/10.15232/S1080-7446(15)31130-X.

Hill, T. M., H. G. Bateman II, J. M. Aldrich, and R. L. Schlotterbeck. 2010. Effect of milk replacer program on digestion of nutrients in dairy calves. J. Dairy Sci. 93:1105-1115. https://doi.org/10.3168/ jds.2009-2458.

Hill, T. M., J. D. Quigley, H. G. Bateman II, F. X. Suarez-Mena, T. S. Dennis, and R. L. Schlotterbeck. 2016. Effect of milk replacer program on calf performance and digestion of nutrients in dairy calves to 4 months of age. J. Dairy Sci. 99:8103-8110. https://doi .org/10.3168/jds.2016-11239.

Hugi, D., S. Gut, and J. Blum. 1997. Blood metabolites and hormones - especially glucose and insulin - in veal calves: Effects of age and nutrition. J. Vet. Med. 44:407-416. https://doi.org/10 $.1111 /$ j.1439-0442.1997.tb01126.x.

Jasper, J., and D. M. Weary. 2002. Effects of ad libitum milk intake on dairy calves. J. Dairy Sci. 85:3054-3058. https://doi.org/10.3168/ jds.S0022-0302(02)74391-9.

Khan, M. A., D. M. Weary, and M. A. G. von Keyserlingk. 2011. Invited review: Effects of milk ration on solid feed intake, weaning, and performance in dairy heifers. J. Dairy Sci. 94:1071-1081. https://doi.org/10.3168/jds.2010-3733.

Krachun, C., J. Rushen, and A. M. de Passillé. 2010. Play behaviour in dairy calves is reduced by weaning and by a low energy intake. Appl. Anim. Behav. Sci. 122:71-76. https://doi.org/10.1016/ j.applanim.2009.12.002.

MacPherson, J. A. R., H. Berends, L. N. Leal, J. P. Cant, J. MartínTereso, and M. A. Steele. 2016. Effect of plane of milk replacer intake and age on glucose and insulin kinetics and abomasal emptying in female Holstein Friesian dairy calves fed twice daily. J. Dairy Sci. 99:8007-8017. https://doi.org/10.3168/jds.2015-10826.

Meale, S. J., L. N. Leal, J. Martin-Tereso, and M. A. Steele. 2015. Delayed weaning of Holstein bull calves fed an elevated plane of nutrition impacts feed intake, growth and potential markers of gastrointestinal development. Anim. Feed Sci. Technol. 209:268-273. https://doi.org/10.1016/j.anifeedsci.2015.08.008.

Ollivett, T. L., D. V. Nydam, T. C. Linden, D. D. Bowman, and M. E. Van Amburgh. 2012. Effect of nutritional plane on health and performance in dairy calves after experimental infection with Cryptosporidium parvum. J. Am. Vet. Med. Assoc. 241:1514-1520. https://doi.org/10.2460/javma.241.11.1514.

Omidi-Mirzaei, H., M. Khorvash, G. R. Ghorbani, B. Moshiri, M. Mirzaei, A. Pezeshki, and M. H. Ghaffari. 2015. Effects of the step-up/step-down and step-down milk feeding procedures on the performance, structural growth, and blood metabolites of Holstein dairy calves. J. Dairy Sci. 98:7975-7981. https://doi.org/10.3168/ jds.2014-9260.

Overton, M. W., R. B. Corbett, and W. G. Boomer. 2013. An economic comparison of conventional vs. intensive heifer rearing. Pages 122-129 in Western Dairy Management Conference Proceedings, Reno, NV. Western Dairy Management Conference, Reno, NV.

Overvest, M. A., R. Bergeron, D. B. Haley, and T. J. DeVries. 2016. Effect of feed type and method of presentation on feeding behavior, intake, and growth of dairy calves fed a high level of milk. J. Dairy Sci. 99:317-327. https://doi.org/10.3168/jds.2015-9997.

Pantophlet, A. J., M. S. Gilbert, J. J. G. C. van den Borne, W. J. J. Gerrits, M. G. Priebe, and R. J. Vonk. 2016. Insulin sensitivity in calves decreases substantially during the first 3 months of life and is unaffected by weaning or fructo-oligosaccharide supplementa- 
tion. J. Dairy Sci. 99:7602-7611. https://doi.org/10.3168/jds.2016 -11084 .

Petitclerc, D., P. Dumoulin, H. Ringuet, J. Matte, and C. Girard. 1999. Plane of nutrition and folic acid supplementation between birth and four months of age on mammary development of dairy heifers. Can. J. Anim. Sci. 79:227-234. https://doi.org/10.4141/ A97-091.

Quigley, J. D., T. M. Hill, T. S. Dennis, F. X. Suarez-Mena, and R. L. Schlotterbeck. 2018. Effects of feeding milk replacer at 2 rates with pelleted, low-starch or texturized, high-starch starters on calf performance and digestion. J. Dairy Sci. 101:5937-5948. https:// doi.org/10.3168/jds.2017-13851.

Quigley, J. D. III, Z. P. Smith, and R. N. Heitmann. 1991. Changes in plasma volatile fatty acids in response to weaning and feed intake in young calves. J. Dairy Sci. 74:258-263. https://doi.org/10.3168/ jds.S0022-0302(91)78168-X.

Radcliff, R. P., M. J. Vandehaar, L. T. Chapin, T. E. Pilbeam, D. K. Beede, E. P. Stanisiewski, and H. A. Tucker. 2000. Effects of diet and injection of bovine somatotropin on prepubertal growth and first-lactation milk yields of Holstein cows. J. Dairy Sci. 83:23-29. https://doi.org/10.3168/jds.S0022-0302(00)74850-8.

Renaville, R., M. Hammadi, and D. Portetelle. 2002. Role of the somatotropic axis in the mammalian metabolism. Domest. Anim. Endocrinol. 23:351-360. https://doi.org/10.1016/S0739 -7240(02)00170-4.

Schaff, C., J. Gruse, J. Maciej, M. Mielenz, E. Wirhgen, A. Hoeflich, M. Schmiche, R. Pfuhl, P. Jawor, T. Stefaniak, and H.H. Hammon. 2016. Effects of feeding milk replacer ad libitum or in restricted amounts for the first five weeks of life on the growth, metabolic adaptation, and immune status of calves. PLoS One:11:e0168974. https://doi.org/10.1371/journal.pone.0168974.

Schlau, N., L. L. Guan, and M. Oba. 2012. The relationship between rumen acidosis resistance and expression of genes involved in regulation of intracellular $\mathrm{pH}$ and butyrate metabolism of ruminal epithelial cells in steers. J. Dairy Sci. 95:5866-5875. https://doi.org/ 10.3168/jds.2011-5167.

Sejrsen, K., and S. Purup. 1997. Influence of prepubertal feeding level on milk yield potential of dairy heifers: a review. J. Anim. Sci. 75:828-835. https://doi.org/10.2527/1997.753828x

Smith, J. M., M. E. Van Amburgh, M. C. Diaz, M. C. Lucy, and D. E. Bauman. 2002. Effect of nutrient intake on the development of the somatotropic axis and its responsiveness to GH in Holstein bull calves. J. Anim. Sci. 80:1528-1537. https://doi.org/10.2527/ 2002.8061528x.

Soberon, F., E. Raffrenato, R. W. Everett, and M. E. Van Amburgh 2012. Pre-weaning milk replacer intake and effects on long term productivity of dairy calves. J. Dairy Sci. 95:783-793. https://doi .org/10.3168/jds.2011-4391.
Stahel, P., J. A. R. MacPherson, H. Berends, M. A. Steele, and J. P. Cant. 2017. Short communication: Parameters of abomasal emptying and glucose-insulin dynamics in Holstein-Friesian calves at 2 ages and 2 levels of milk replacer intake. J. Dairy Sci. 100:50685072. https://doi.org/10.3168/jds.2016-12225.

Steele, M. A., G. Vandervoort, O. AlZahal, S. Hook, J. C. Matthews, and B. W. McBride. 2011. Rumen epithelial adaptation to highgrain diets involves the coordinated regulation of genes involved in cholesterol homeostasis. Physiol. Genomics 43:308-316. https:/ /doi.org/10.1152/physiolgenomics.00117.2010.

Strzetelski, J., B. Niwinska, J. Kowalczyk, and A. Jurkiewicz. 2001. Effect of milk repalcer feeding frequency and level of concentrate intake and rearing performance of calves. J. Anim. Feed Sci. 10:413-420. https://doi.org/10.22358/jafs/67995/2001.

Sweeney, B. C., J. P. Rushen, D. M. Weary, and A. M. B. de Passillé 2010. Duration of weaning, starter intake, and weight gain of dairy calves fed large amounts of milk. J. Dairy Sci. 93:148-152. https:/ /doi.org/10.3168/jds.2009-2427.

Takahashi, H., Y. Kurose, S. Kobayashi, T. Sugino, M. Kojima, K. Kangawa, Y. Hasegawa, and Y. Terashima. 2006. Ghrelin enhances glucose-induced insulin secretion in scheduled meal-fed sheep. J. Endocrinol. 189:67-75. https://doi.org/10.1677/joe.1.06310.

Terré, M., M. Devant, and A. Bach. 2007. Effect of level of milk replacer fed to Holstein calves on performance during the preweaning period and starter digestibility at weaning. Livest. Sci. 110:82-88. https://doi.org/10.1016/j.livsci.2006.10.001.

Thomas, T. J., D. M. Weary, and M. C. Appleby. 2001. Newborn and 5 -week-old calves vocalize in response to milk deprivation. Appl. Anim. Behav. Sci. 74:165-173. https://doi.org/10.1016/S0168 -1591(01)00164-2

van Niekerk, J. K., A. J. Fischer-Tlustos, L. L. Deikun, J. D. Quigley, T. Dennis, X. Suarez-Mena, T. M. Hill, R. Schlotterbeck, L. L. Guan, and M. A. Steele. 2020. Impact of amount of milk replacer fed and the processing of corn in starter on growth performance, nutrient digestibility and rumen and fecal fibrolytic bacteria of dairy calves. J. Dairy Sci. 103:2186-2199. https://doi.org/10 .3168/jds.2019-17372.

Whitlock, B. K., M. J. VandeHaar, L. F. P. Silva, and H. A. Tucker. 2002. Effect of dietary protein on prepubertal mammary development in rapidly growing dairy heifers. J. Dairy Sci. 85:1516-1525. https://doi.org/10.3168/jds.S0022-0302(02)74221-5.

Yunta, C., M. Terré, and A. Bach. 2015. Short- and medium-term changes in performance and metabolism of dairy calves offered different amounts of milk replacers. Livest. Sci. 181:249-255. https:/ /doi.org/10.1016/j.livsci.2015.09.008. 